\title{
Article
}

\section{The Phylogenetic Structure of Reptile, Avian and Uropathogenic Escherichia coli with Particular Reference to Extraintestinal Pathotypes}

\author{
Marta Książczyk ${ }^{1}$ **, Bartłomiej Dudek ${ }^{1}$, Maciej Kuczkowski ${ }^{2}$, Robert O'Hara ${ }^{3}$, Kamila Korzekwa ${ }^{1}$, \\ Anna Wzorek ${ }^{4}$, Agnieszka Korzeniowska-Kowal ${ }^{4}$, Mathew Upton ${ }^{5}$, Adam Junka ${ }^{(\mathbb{D}}$, Alina Wieliczko ${ }^{2}$, \\ Radosław Ratajszczak ${ }^{7}$ and Gabriela Bugla-Płoskońska ${ }^{1, *(D)}$
}

1 Department of Microbiology, Institute of Genetics and Microbiology, University of Wrocław, 51-148 Wrocław, Poland; bartlomiej.dudek@uwr.edu.pl (B.D.); kamila.korzekwa@uwr.edu.pl (K.K.)

2 Department of Epizootiology and Clinic of Bird and Exotic Animals, Wrocław University of Environmental and Life Sciences, 50-366 Wrocław, Poland; maciej.kuczkowski@upwr.edu.pl (M.K.); alina.wieliczko@upwr.edu.pl (A.W.)

3 Virology Department, Manchester University NHS Foundation Trust, Manchester M13 9WL, UK; Robert.O'Hara@mft.nhs.uk

4 Polish Collection of Microorganisms PCM, Department of Immunology of Infectious Diseases, Hirszfeld Institute of Immunology and Experimental Therapy, Polish Academy of Sciences, 53-114 Wrocław, Poland anna.wzorek@hirszfeld.pl (A.W.); agnieszka.korzeniowska-kowal@hirszfeld.pl (A.K.-K.)

5 School of Biomedical \& Healthcare Sciences, Faculty of Health, University of Plymouth, Plymouth PL4 8AA, UK; mathew.upton@plymouth.ac.uk

check for updates

Citation: Książczyk, M.; Dudek, B.; Kuczkowski, M.; O’Hara, R.;

Korzekwa, K.; Wzorek, A.;

Korzeniowska-Kowal, A.; Upton, M.; Junka, A.; Wieliczko, A.; et al. The Phylogenetic Structure of Reptile, Avian and Uropathogenic Escherichia coli with Particular Reference to

Extraintestinal Pathotypes. Int. J. Mol. Sci. 2021, 22, 1192. https://doi.org/ 10.3390/ijms22031192

Received: 3 November 2020

Accepted: 18 December 2020

Published: 26 January 2021

Publisher's Note: MDPI stays neutral with regard to jurisdictional claims in published maps and institutional affiliations.

Copyright: (c) 2021 by the authors. Licensee MDPI, Basel, Switzerland. This article is an open access article distributed under the terms and conditions of the Creative Commons Attribution (CC BY) license (https:// creativecommons.org/licenses/by/ $4.0 /)$.
6 Department of Pharmaceutical Microbiology and Parasitology, Medical University of Wrocław, 50-556 Wrocław, Poland; adam.junka@umed.wroc.pl

7 Zoological Garden in Wrocław, 51-618 Wrocław, Poland; r.ratajszczak@zoo.wroc.pl

* Correspondence: marta.ksiazczyk@uwr.edu.pl (M.K.); gabriela.bugla-ploskonska@uwr.edu.pl (G.B.-P.)

\begin{abstract}
The impact of the Gram-negative bacterium Escherichia coli (E. coli) on the microbiomic and pathogenic phenomena occurring in humans and other warm-blooded animals is relatively wellrecognized. At the same time, there are scant data concerning the role of E. coli strains in the health and disease of cold-blooded animals. It is presently known that reptiles are common asymptomatic carriers of another human pathogen, Salmonella, which, when transferred to humans, may cause a disease referred to as reptile-associated salmonellosis (RAS). We therefore hypothesized that reptiles may also be carriers of specific E. coli strains (reptilian Escherichia coli, RepEC) which may differ in their genetic composition from the human uropathogenic strain (UPEC) and avian pathogenic E. coli (APEC). Therefore, we isolated RepECs $(n=24)$ from reptile feces and compared isolated strains' pathogenic potentials and phylogenic relations with the aforementioned UPEC $(n=24)$ and APEC $(n=24)$ strains. To this end, we conducted an array of molecular analyses, including determination of the phylogenetic groups of $E$. coli, virulence genotyping, Pulsed-Field Gel Electrophoresis-Restriction Analysis (RA-PFGE) and genetic population structure analysis using Multi-Locus Sequence Typing (MLST). The majority of the tested RepEC strains belonged to nonpathogenic phylogroups, with an important exception of one strain, which belonged to the pathogenic group B2, typical of extraintestinal pathogenic E. coli. This strain was part of the globally disseminated ST131 lineage. Unlike RepEC strains and in line with previous studies, a high percentage of UPEC strains belonged to the phylogroup B2, and the percentage distribution of phylogroups among the tested APEC strains was relatively homogenous, with most coming from the following nonpathogenic groups: C, A and B1. The RA-PFGE displayed a high genetic diversity among all the tested E. coli groups. In the case of RepEC strains, the frequency of occurrence of virulence genes (VGs) was lower than in the UPEC and APEC strains. The presented study is one of the first attempting to compare the phylogenetic structures of E. coli populations isolated from three groups of vertebrates: reptiles, birds and mammals (humans).
\end{abstract}

Keywords: extraintestinal E. coli; phylogenetic analysis; virulence genes 


\section{Introduction}

The complex phylogenetic structure of Escherichia coli species [1-3] is strong evidence for the clonal evolution of this bacterium; however, recent publications suggest that recombination processes are playing a greater significant role [4-8]. Four main phylogenetic groups of E. coli have been determined. Groups A and B1 mainly include nonpathogenic commensal E. coli strains, while extraintestinal pathogenic E. coli are clustered to groups B2 and D [8-10]. The use of Multi-Locus Sequence Typing (MLST) has enabled a more accurate determination of the phylogenetic structure of E. coli species by targeting their housekeeping genes and assigning strains to an appropriate Sequence Type (ST) $[9,11,12]$. As a result, not only new hybrid phylogroups of E. coli have been discovered [13], but it has also been revealed that $80-85 \%$ of E. coli strains might have been previously assigned to incorrect phylogenetic groups $[14,15]$. Therefore, new phyllo groups have been formed and referred to as group C, which contains nonpathogenic strains of E. coli, closely related to representatives of the B1 group [16], group E, whose representatives (including, among others, E. coli O157:H7 strains) are associated with strains of group D [13-15] and, finally, group F, clustering extraintestinal pathogenic E. coli closely related with the B2 group representatives [13]. In addition to the aforementioned main groups, a phylogenetic unit referred to as the "cryptic clade" has been distinguished, consisting of new species of the genus Escherichia [17]. The latest Clermont report revealed a new group intermediate between the F and B2 phylogroups, which has been designated as phylogroup $G$ [18].

Extraintestinal E. coli (ExPEC) strains are clustered in the groups B2, E, D and F and characterized by great diversity with regards to the sets of virulence factors, mechanisms of the pathogenesis and types of resulting infections. Therefore, these strains are assigned to various pathotypes. It has been determined that the ExPEC strains isolated from humans and other warm-blooded animals (cats, dogs, pigs, cattle and fowl) are of high genetic similarity, which is believed to be a result of the high plasticity of the E. coli genome and of the transmission of E. coli between humans and these animals [19-22]. Due to the wide prevalence and significant role of ExPEC in the pathogenesis, these strains have been the subject of intense scientific investigations [23,24]. At the same time, the knowledge of the virulence traits and genetic compositions of the E. coli strains isolated from cold-blooded animals is extremely sparse; only a few reports have been published on the isolation of $E$. coli strains from the intestines of reptiles $[25,26]$.

Increasing overpopulation and environmental pollution lead to an increased exposure of wild-living animals to wastes containing human pathogens, such as E. coli. Since reptiles are frequent carriers of Gram-negative pathogenic bacteria, including Salmonella, which is able to cause a serious disease called Reptile-Associated Salmonellosis (RAS) [27], we hypothesized that reptiles may also carry other Gram-negative bacteria, such as ExPEC, as their natural microbiota and transmit them [28].

Therefore, the main aim of the present study was to determine the phylogenetic relationships of the RepEC, UPEC and APEC strains and to assess the distribution of virulence genes (VGs) in their genomes.

\section{Results}

Among all bacterial strains isolated from reptile's feces and assigned to the E. coli species using biochemical testing and a Matrix-Assisted Laser Desorption/Ionization Time-of-Flight Mass Spectrometry (MALDI-TOF MS) analysis, (RepEC strains $(n=35)$ include: strains from snakes $(n=15)$, strains from turtles $(n=14)$ and from lizards $(n=6))$, we selected to further study 24 strains. The datasets analyzed during the current study are available from the Polish Collection of Microorganisms PCM (Wroclaw, Poland) on reasonable request. E. coli were identified using MALDI-TOF MS with log scores ranging from 2.205 to 2.878 , which indicate highly probable and probable species identification, respectively. 


\subsection{Phylogenetic Groups of E. coli}

The assignment of the RepEC, UPEC and APEC strains to the respective phylogroups is presented in Figures 1 and A1, Figures A2 and A3 (Appendix A). The results presented in Figures 1 and $\mathrm{A} 1$ indicate that $92 \%$ and $5 \%$ of RepEC strains belonged to the nonpathogenic $\mathrm{B} 1$ and C groups, respectively. It should be noted here that one RepEC strain, namely 209E, belonged to the pathogenic B2 phylogroup.

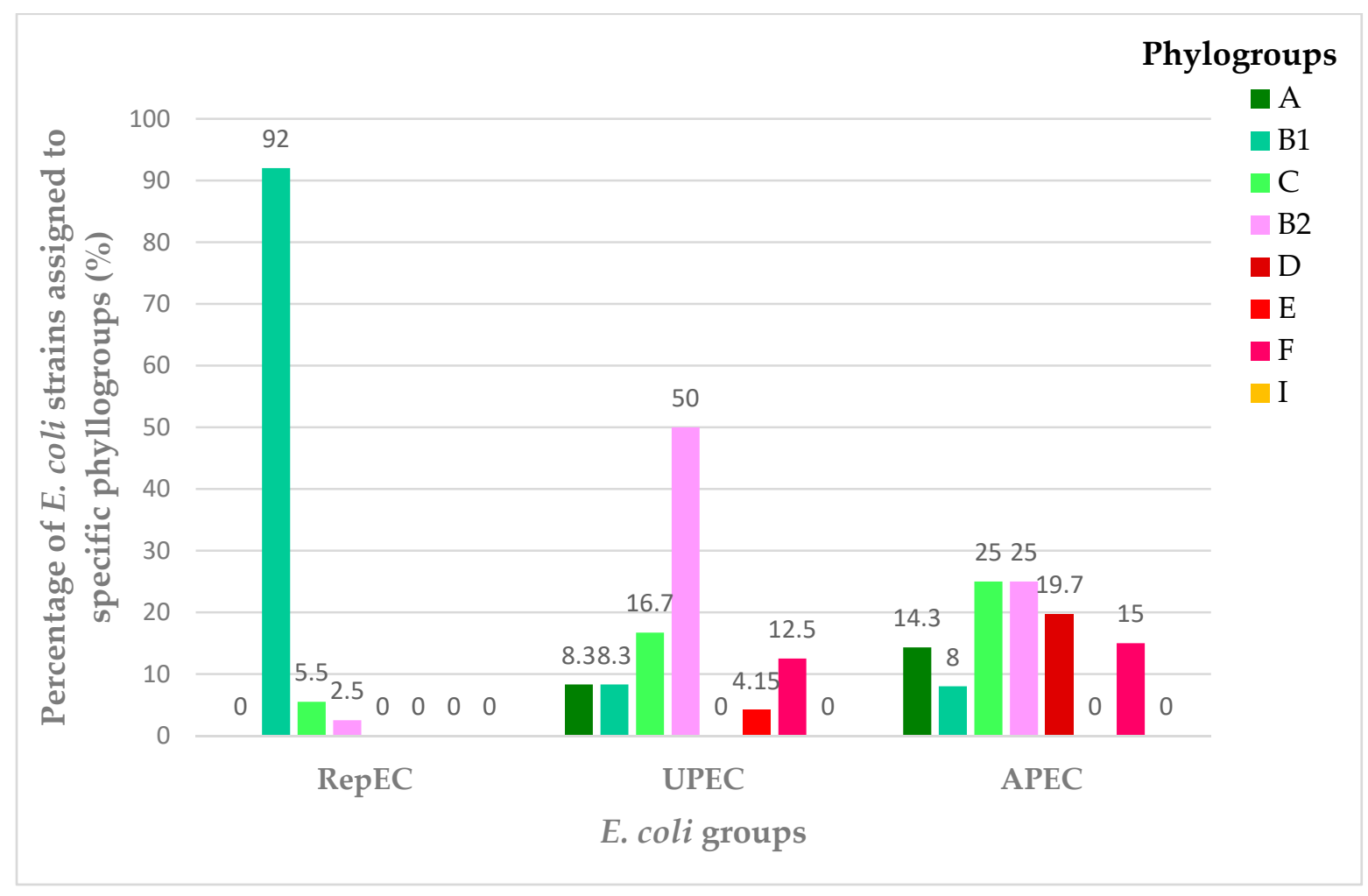

Figure 1. This percentage (\%) share of Escherichia coli $(n=72)$ strains belonging to specific phylogroups. RepEC-E. coli strains isolated from reptiles $(n=24)$, UPEC—uropathogenic E. coli strains $(n=24)$ and APEC-avian pathogenic E. coli strains causing colibacillosis $(n=24)$. Phylogroups: A and B1 predominantly include nonpathogenic commensal $E$. coli strains, B2 and D include extraintestinal pathogenic E. coli, C contains nonpathogenic strains of E. coli, closely related with representatives of group B1, E is represented by strains closely related with phylogroup D (including, among others, E. coli O157:H7 strains) and F clusters extraintestinal pathogenic E. coli closely related with group B2 representatives.

A high percentage of UPEC strains belonged to the B2 phylogroup $(50 \%)(n=12)$. The percentage shares of specific UPEC strains within the remaining commensal phylogroups were as follows: $17 \%$ of UPEC strains $(n=4)$ belonged to Group C, $13 \%(n=3)$ were Group E, $8 \%(n=2)$ belonged to group A, $8 \%(n=2)$ belonged to group B1 and $4 \%(n=1)$ were from Group D (Figures 1 and A2). The percentage distribution of the phylogroups among the tested APEC strains was relatively homogenous (Figures 1 and A3). They belonged to the following nonpathogenic groups: C $(25 \%, n=7), \mathrm{B} 2(25 \%, n=7), \mathrm{E}(18 \%, n=5), \mathrm{F}(14 \%$, $n=4), \mathrm{A}(11 \%, n=3)$ and $\mathrm{B} 1(7 \%, n=2)$.

\subsection{Virulence Gene Typing}

Figure 2 presents a map containing VGs profiles of specific RepEC strains. The VG score for the RepEC strains ranged from 0 (strain 148E and 152E) to 5 (strain 305C). Except for the fim $C$ gene (the prevalence of fim $C$ for RepEC equaled 100\%), the frequency of other tested VGs among RepEC was low or very low. The frequency of VGs detected in RepEC was as follows: astA (8\%), iss (4\%), irp2 (8\%), papC (4\%), fyuA $(8 \%)$, kpsII $(29 \%)$ and traT $(16 \%)$. Other VGs targeted were not detected among the RepEC strains. 


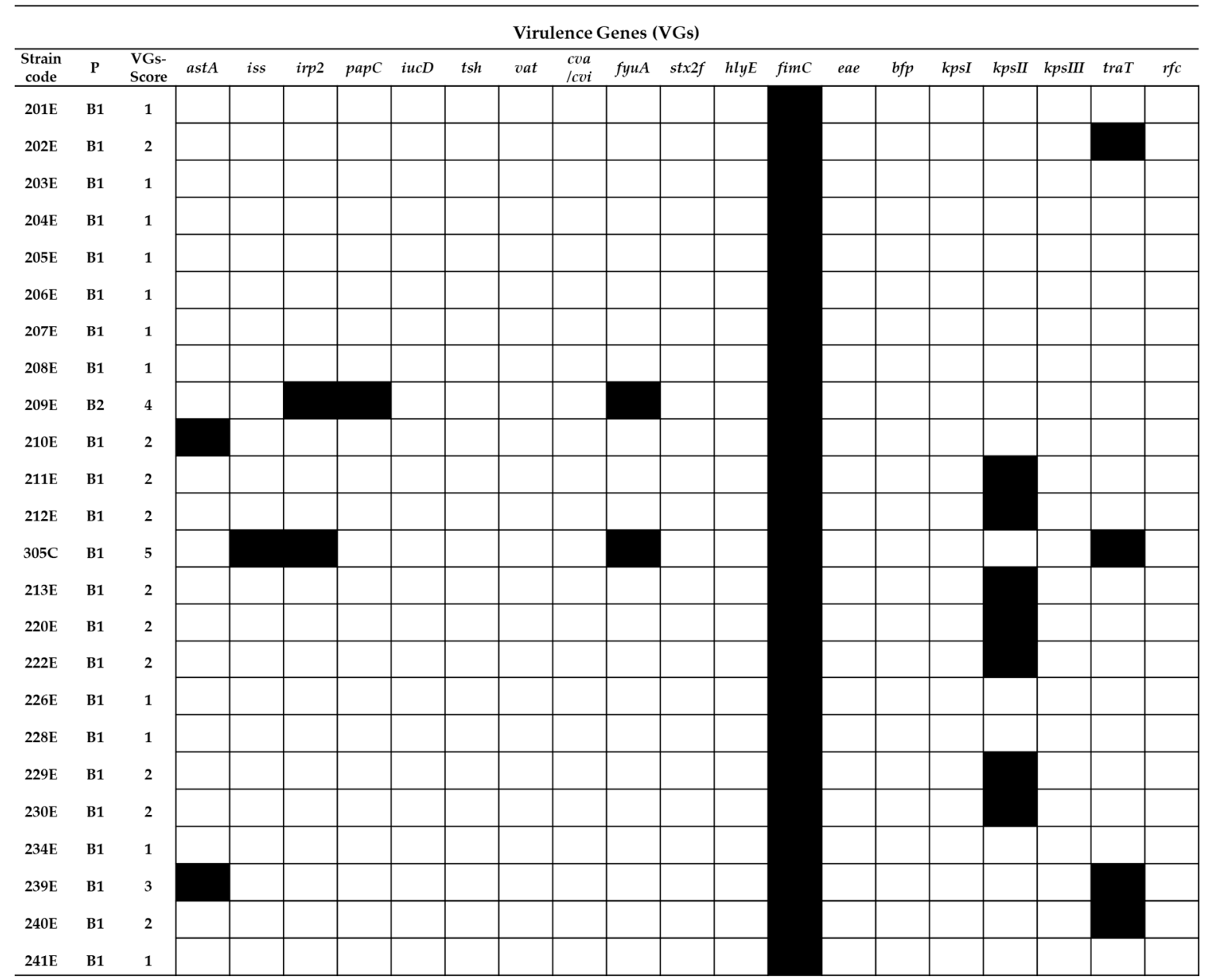

Figure 2. Virulence gene (19 VG) profiles of the tested RepEC strains $(n=24)$. P-phylogenetic group,

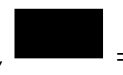
$=$ presence of the gene and $\square=$ absence of the gene.

The analyzed UPEC strains (Figure 3) displayed a high prevalence of VGs: irp2 92\%, iucD $54 \%$, fuy $A 62.5 \%$, papC $54 \%$, traT $62.5 \%$ and $k p s I 54 \%$. The VG score for the UPEC strains ranged from 4 (strains 15607.35, 15550.25, 15599.34 and 1119) to 9 (strains 15279.21, 15593.39 and 15300.22). The presence of the following VGs were not detected among the tested UPEC strains: $s t x 2 f$, hlyE, eae and $b f p$.

The APEC strains (Figure 4) were characterized by high and very high prevalence of the following VGs: iss 76\%, fyuA 92\%, irp2 62.5\%, iucD 70\%, kpsI $29 \%$ and $k p s I I 33 \%$. The VG score values determined for APEC strains ranged from 2 (strain 169) to 10 (strain 188). The presence of the following VGs were not detected among the tested APEC strains: cva/cvi, stx2f, eae, bfp and kpsIII.

In general, the frequency of occurrence of VGs in the RepEC strains was lower than in the UPEC and APEC strains (Figure 5). Only two noticeable exceptions were observed. One concerned the prevalence of the fim C gene, which was detected in $100 \%$ of the RepEC and UPEC isolates and $96 \%$ of the APEC isolates, while the other concerned the prevalence of the kpsII gene, whose frequency of occurrence was comparable between RepEC, UPEC and APEC $(29 \%, 33 \%$ and $33 \%$, respectively).

The following E. coli strains were selected for further analysis with the use of PulsedField Gel Electrophoresis-Restriction Analysis (RAE-PFGE) and MLST: UPEC 15279.21, 1119 and 15035.8; APEC1288, 1239, 189A and 60C and RepEC 200E, 209E, 212E and 305C. The rationale behind this choice was the prevalence of one of the following VGs: iss, tratT, kpsII and $r f c$. 


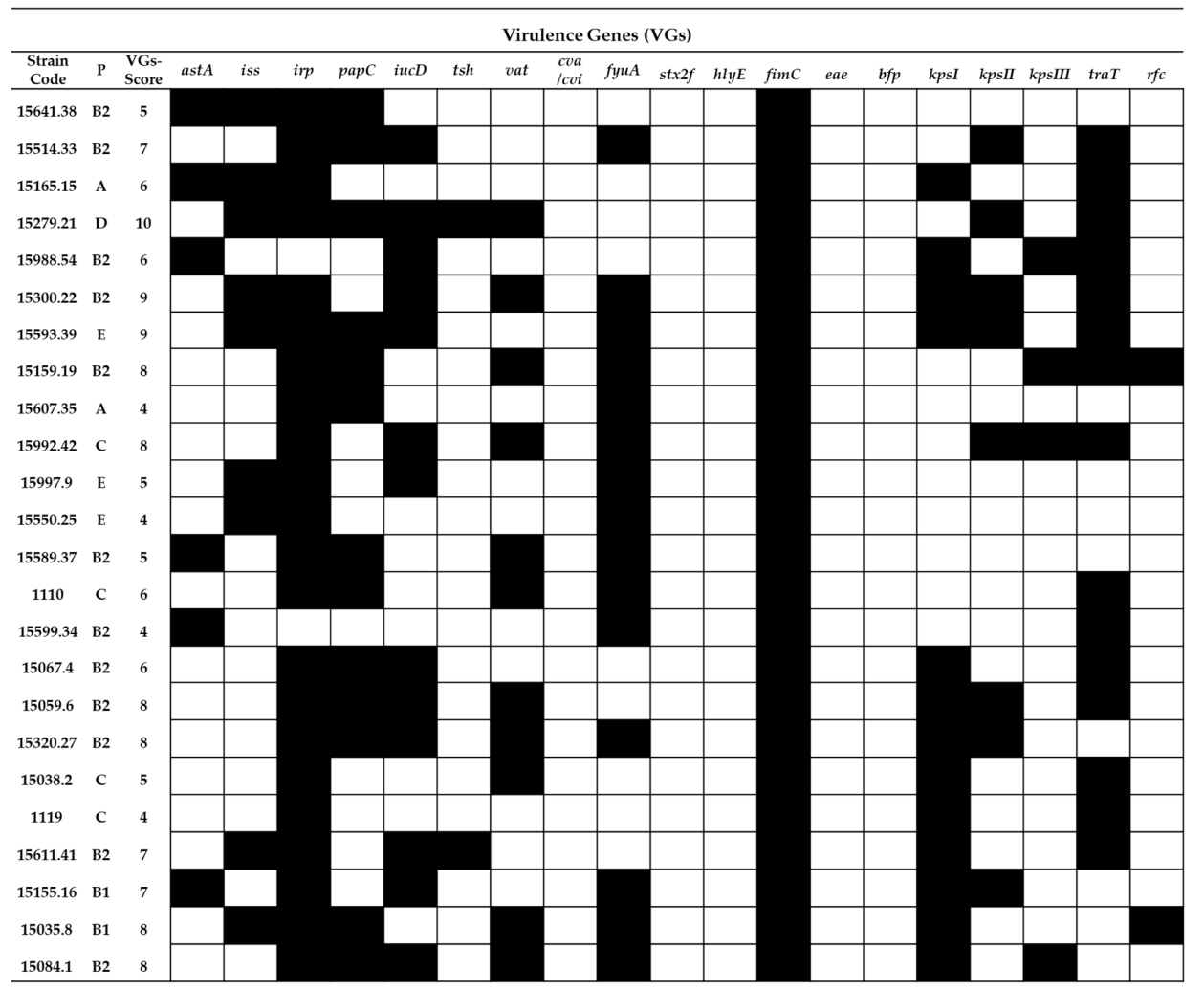

Figure 3. Virulence gene $(19 \mathrm{VG})$ profiles of the tested UPEC strains $(n=24)$. P-phylogenetic group, $=$ presence of the gene and $\square=$ absence of the gene.

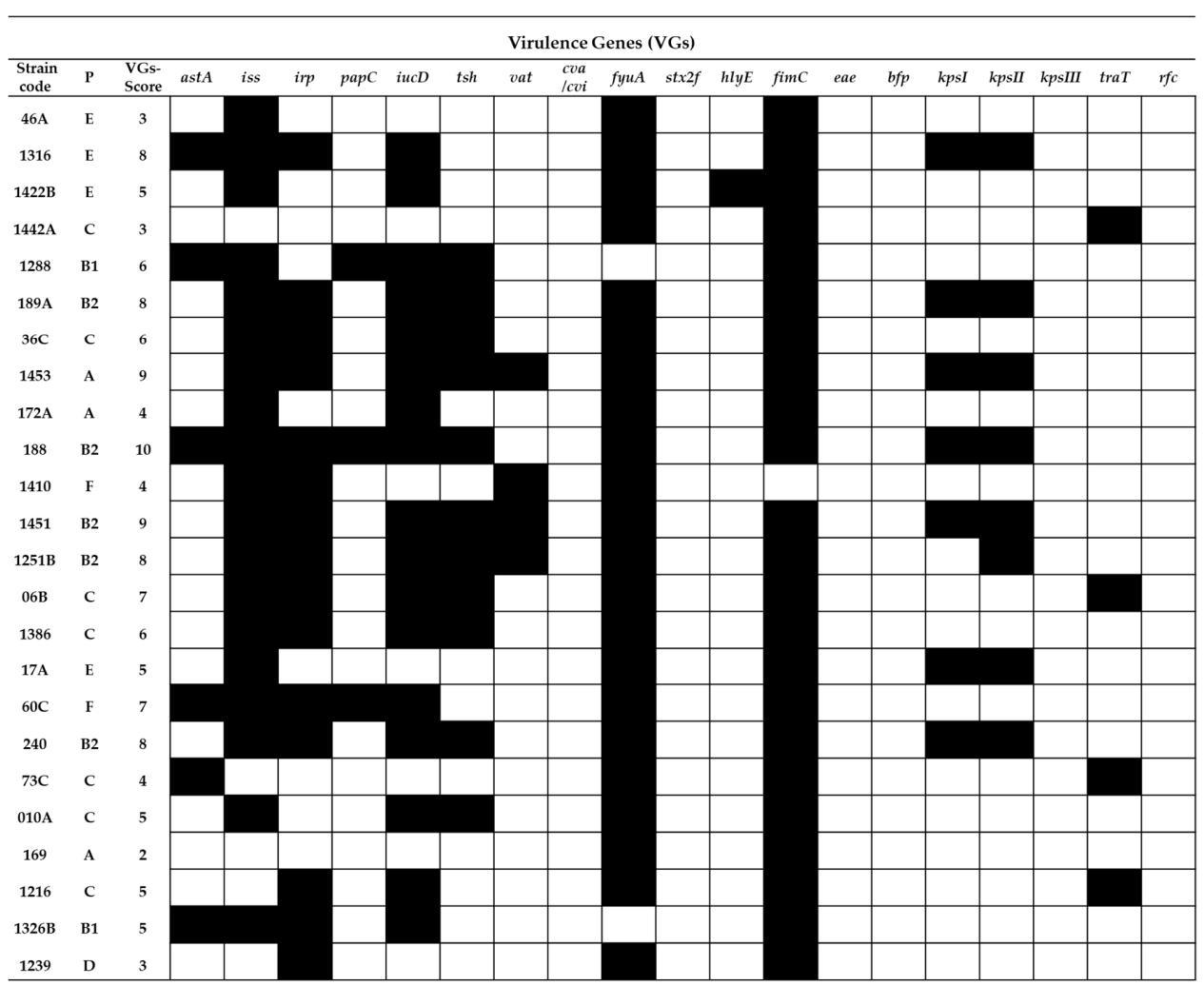

Figure 4. Virulence gene (19 VG) profiles of the tested APEC strains $(n=24)$. P-phylogenetic group, $\square=$ presence of the gene and $\square=$ absence of the gene. 


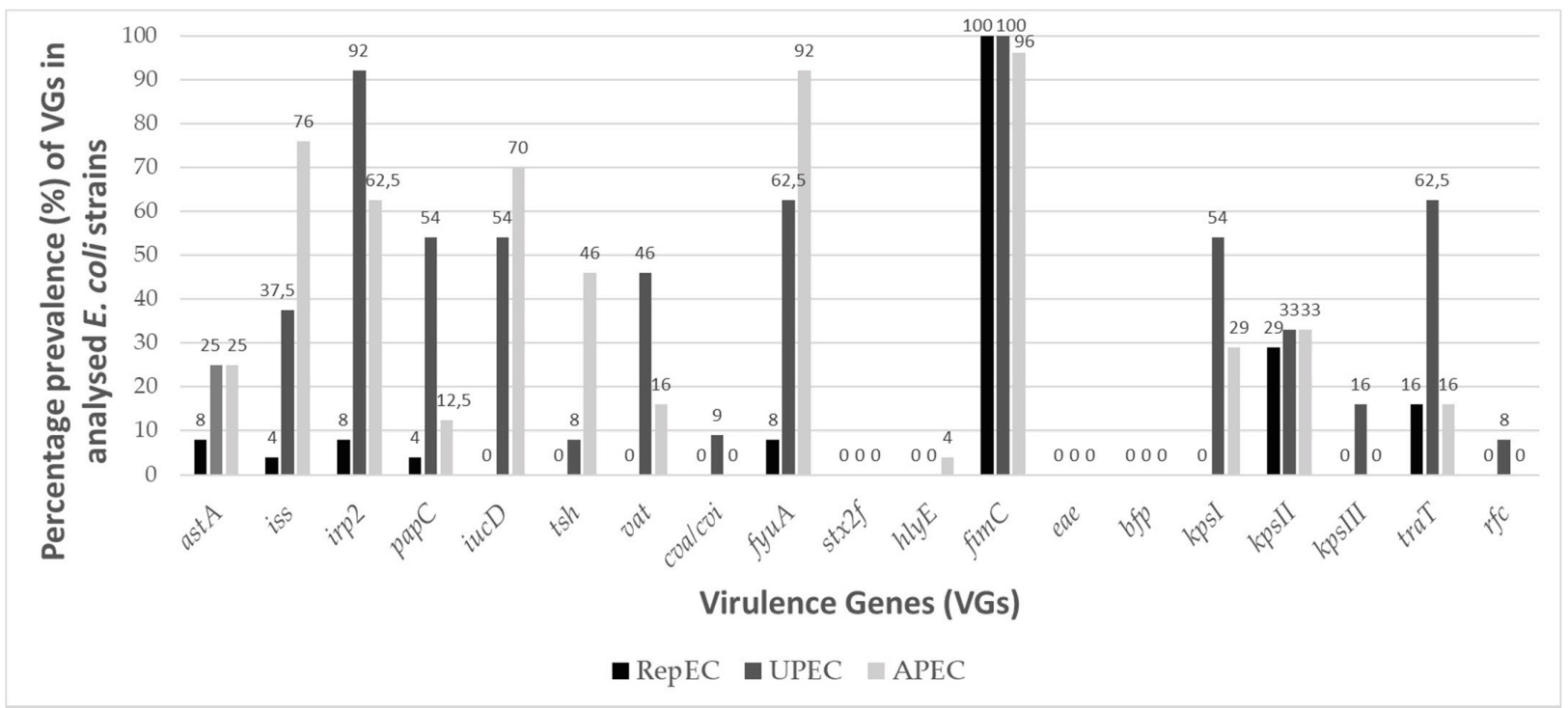

Figure 5. The percentage prevalence of VGs among the RepEC $(n=24)$, UPEC $(n=24)$ and APEC strains $(n=24)$.

\subsection{Analysis of Phylogenetic Relationships between E. coli Strains from Different Hosts}

The Pulsed-Field Gel Electrophoresis with Restriction Analysis (RAE-PFGE) was conducted, resulting in restriction profiles of 41 DNA fragments displaying high diversity (Figure 6). Each of the tested E. coli strains had a unique restriction profile that differed by at least one DNA fragment from the other strains. Additionally, strain $60 \mathrm{C}$ (belonging to the APEC pathogroup) appeared to be nontypeable.

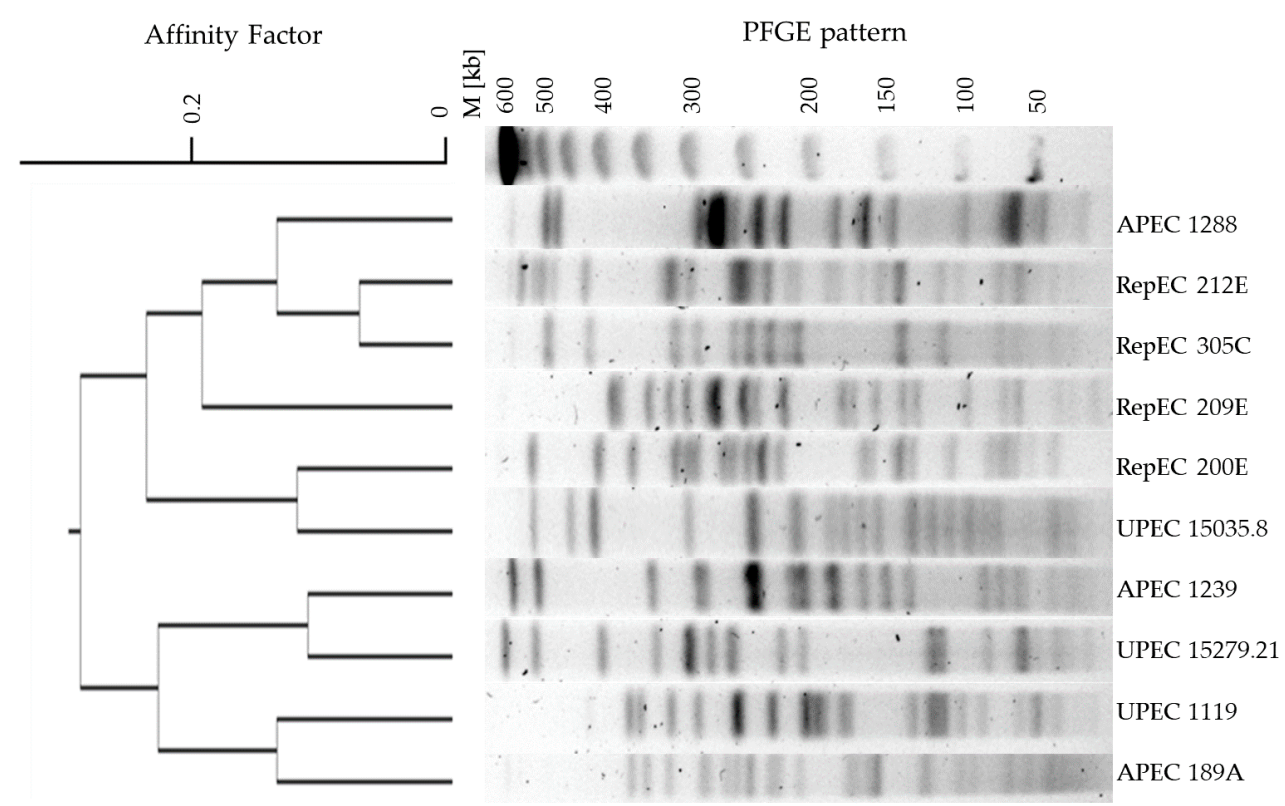

Figure 6. Dendrogram displaying the relationships between the selected selected $E$. coli strains $(n=10)$, including RepEC $(n=4)$, UPEC $(n=3)$ and APEC $(n=3)$, based on the results of the Pulsed-Field Gel Electrophoresis-Restriction Analysis (RAE-PFGE). The dendrogram was created using the Unweighted Pair Group Method with Arithmetic Mean (UPGMA) method. (http://insilico.ehu.es/dice_upgma/index.php). M-molecular weight marker. 


\subsection{Multi-Locus Sequence Typing}

The assignment of E. coli strains to specific STs was performed by means of MultiLocus Sequence Typing (MLST). The results of the MLST analysis and detailed descriptions of the STs assigned to the tested E. coli strains are presented in Table 1.

Table 1. Results of the assignment of selected Escherichia coli strains $(n=11)$, including the reptilian E. coli $(\operatorname{RepEC})(n=4)$, uropathogenic strain (UPEC) $(n=3)$ and avian pathogenic strain (APEC) $(n=4)$, to the Sequence Type on the basis of their allelic profiles of their house-keeping genes (allelotypes) and descriptions of the STs according to the Warwick University Multi-Locus Sequence Typing (MLST) database. P-phylogroup.

\begin{tabular}{|c|c|c|c|c|c|}
\hline Group of E. coli & $\begin{array}{c}\text { E. coli } \\
\text { Strain Code }\end{array}$ & $\mathbf{P}$ & $\begin{array}{c}\text { Asigned } \\
\text { Sequence Type }\end{array}$ & Description of STs & Citations \\
\hline \multirow{3}{*}{ UPEC $(n=3)$} & 15279.21 & $\mathrm{D}$ & ST321 & $\begin{array}{l}\text { ST321 is characteristic of } \\
\text { nonpathogenic E. coli strains isolated } \\
\text { from wild animals. }\end{array}$ & [29] \\
\hline & 1119 & $\mathrm{C}$ & ST410 & $\begin{array}{l}\text { which includes pathogenic E. coli } \\
\text { strains (human UPEC strains, } \\
\text { predominantly). }\end{array}$ & {$[29,30]$} \\
\hline & 15035.8 & B1 & ST12 & $\begin{array}{c}\text { ST12 is typical of extraintestinal } \\
\text { pathogenic E. coli strains causing } \\
\text { systemic infections in warm-blooded } \\
\text { animals and also typical of } E \text {. coli } \\
\text { causing urinary tract infections (UTIs) } \\
\text { among humans. }\end{array}$ & {$[29,31]$} \\
\hline \multirow{4}{*}{$\operatorname{APEC}(n=4)$} & 1288 & B1 & ST1582 & $\begin{array}{l}\text { ST1582 is characteristic for UPEC } \\
\text { strains causing UTIs in horses. }\end{array}$ & [29] \\
\hline & 1239 & $\mathrm{D}$ & ST665 & $\begin{array}{l}\text { ST665 is typical of nonpathogenic } E . \\
\text { coli strains isolated from poultry. }\end{array}$ & {$[29,32]$} \\
\hline & 189A & B2 & ST131 & $\begin{array}{l}\text { ST131 is a globally disseminated clone } \\
\text { that poses a substantial health risk to } \\
\text { humans, causing acute extraintestinal } \\
\text { infections, such as serious UTI, } \\
\text { urosepsis and sepsis. }\end{array}$ & {$[8,29,33,34]$} \\
\hline & $60 \mathrm{C}$ & & ST117 & $\begin{array}{l}\text { ST117, which is a heterogenic group of } \\
\text { extraintestinal pathogenic E. coli } \\
\text { strains. }\end{array}$ & {$[29,35]$} \\
\hline \multirow{4}{*}{ REPEC $(n=4)$} & $200 \mathrm{E}$ & B1 & ST446 & $\begin{array}{l}\text { ST446 is typical of APEC strains and } \\
\text { also of other human pathogenic } \\
\text { extraintestinal E. coli. }\end{array}$ & {$[29,36]$} \\
\hline & $209 \mathrm{E}$ & B2 & ST681 & $\begin{array}{c}\text { ST } 681 \text { includes } E \text {. coli strains } \\
\text { pathogenic for humans and other } \\
\text { animals. }\end{array}$ & {$[29,37]$} \\
\hline & $212 \mathrm{E}$ & B1 & ST212 & $\begin{array}{l}\text { This heterogenous ST mainly includes } \\
\text { UPEC strains as well as other } \\
\text { pathogenic and nonpathogenic E. coli } \\
\text { strains. }\end{array}$ & {$[29,38]$} \\
\hline & $305 C$ & B1 & New ST! & $\begin{array}{l}\text { Strain 305C could not be assigned to } \\
\text { any known ST, although it could be a } \\
\text { member of the ST } 88 \text { clonal complex } \\
\text { (with differences in two alleles } a d k \text { and } \\
m d h ; \text { unconfirmed data). }\end{array}$ & - \\
\hline
\end{tabular}

\section{Discussion}

Escherichia coli species display a high genetic diversity, genome plasticity and adaptability to different ecological niches. E. coli are part of the microbiota of warm-blooded animals and may act as pathogens causing intestinal or extraintestinal infections posing a serious threat to health and survival $[38,39]$. 
Pathogenic E. coli strains, including extraintestinal pathogenic Escherichia coli (ExPEC), have different virulence genes and different mechanisms of pathogenesis, causing a broad range of diseases. The ExPEC include UPEC, Neonatal Meningitidis E. coli (NMEC), Sepsis Causing E. coli (SEPEC) and APEC [39]. Due to their high capacity for adaptation, ExPEC strains may spread and thrive in different environments. From an ecological and epidemiological perspective, it is of paramount importance to establish the possible routes of contamination by these bacteria in humans and other species (both domesticated and wild-living). A genetic analysis is one of the most important tools serving this purpose. Warm-blooded animals (cats, dogs, cattle, pigs and horses) are already-known reservoirs of ExPEC strains [39,40], but knowledge about the occurrence of E. coli in cold-blooded animals is extremely scant. It should be noted that cold-blooded reptiles are frequent asymptomatic carriers of Salmonella, a Gram-negative microbe closely related to E. coli. Salmonella that may cause a severe disease called Reptile-Associated Salmonellosis [41]. In consideration of the above-presented facts, we hypothesized that $E$. coli may also inhabit the digestive tract of reptiles. Our aim was not only to fill the gap in the knowledge of the composition of intestinal microbes in reptiles but, most of all, to determine whether these cold-blooded animals may be a source of ExPEC pathotypes, which are widely disseminated in the natural environment. In order to address these issues, we conducted a thorough genetic analysis of $E$. coli strains isolated from reptiles (RepEC) and compared findings with the results of an analysis of two well-known pathotypes of E. coli, namely UPEC and APEC.

According to the authors' best knowledge, there are very few reports on the isolation of $E$. coli from reptiles [25,42]. In 2017, 142 E. coli strains were isolated from 60 exotic reptiles seized during an airport customs inspection in Frankfurt [43]. In Brazil, nine strains of E. coli were collected from 78 lizards [44]; screening tests of 447 wild-live reptiles resulted in the isolation of 45 E. coli strains in Austria [32], whereas, in Germany, two E. coli isolates were detected in 56 domesticated and wild-living reptiles [42]. Two other screening exercises conducted in Australia [45] and in Cuba [26] confirmed that the prevalence of E. coli in the intestinal microbiome is significantly lower in cold-blooded animals compared with warm-blooded ones. In the majority of the previous studies [26,45], no attempts were made to characterize the E. coli isolates at the genetic level. In our study, we isolated 24 E. coli strains from 120 feces samples collected from reptiles belonging to the collection of the Zoological Garden in Wrocław. Therefore, our data are consistent with the abovementioned reports $[25,26]$, and they indicate that the prevalence of $E$. coli in the microbiota of reptiles may be considered to be low. The prevalence of $E$. coli in reptiles in Poland has not been reported previously. E. coli strains isolated from reptiles may display phenotypic traits typical of pathogenic $E$. coli strains. The strains isolated from reptile feces in Cuba had highly mucoid colonies and were hemolytic when grown on agar containing ovine blood 26]. This observation is consistent with our previous findings in the identification procedure of E. coli with ambiguous phenotypes, isolated from the feces of a Bell's Hingeback Tortoise (Kinixys belliana) [46]. The isolated RepEC strain, referred to as strain 305C in the current study, had a mucoid colony morphology and a thick cell capsule, characteristic of the genus Klebsiella. Using the MALDI-TOF MS analysis, the strain referred to above was assigned to the species Citrobacter braakii; however, biochemical tests indicated that it belongs to the $E$. coli species. The conclusive results were finally obtained with the use of $16 \mathrm{~S}$ rRNA gene sequencing and confirmed that the strain was a member of the E. coli species [46], and further studies revealed this 305C RepEC strain may belong not to the previously described Sequence Type but belong to the ST88 clonal complex. ST88 includes ExPEC strains (UPEC, APEC and SEPEC) [29]. Therefore, determination of the 305C RepEC strain to any known ST confirms its unique and atypical traits. As previously mentioned, our aim was to characterize RepEC strains with genetic analysis tools by comparing three E. coli groups from different sources. The present study is the first to communicate the phylogenetic comparison of E. coli strains isolated from three classes of vertebrates, i.e., reptiles, mammals and birds. In the first experimental setting, we 
determined the phylogroups for the RepEC strains (Figures 1,A1-A3). The majority (95\%) of them were assigned to the nonpathogenic phylogroup B1. The results obtained are consistent with those presented by Gordon and colleagues, who tested the prevalence of Enterobacteriaceae among mammals, birds and cold-blooded animals in Australia [45]. In the case of cold-blooded animals, E. coli belonging to the phylogroup B2 were very rarely isolated [45]. In our study, one RepEC strain 209E was assigned to the phylogroup B2, typical of ExPEC strains. A majority of the UPEC and APEC strains were assigned to the group B2 (50\% and 25\%, respectively). Only $8.3 \%$ and $7 \%$ of the UPEC and APEC strains, respectively, were assigned to the group $\mathrm{B} 1$.

There are no reports describing the prevalence of VGs in RepEC strains in the global scientific literature. In our study, we determined that RepEC strains show a low prevalence of VGs (VG score: 0-5) in comparison with the tested UPEC (VG score: 4-9) and APEC strains (VG score: 2-10). One of the two noticeable exceptions was the gene fim C present in $96 \%$ of the RepEC strains. This may be explained by the fact that this gene is essential for the production of type I fimbriae, a universal virulence factor [47] ubiquitous within the species. The foregoing assumption may be additionally confirmed by the fact that, in our study, the fim C gene was also detected in $100 \%$ and $98 \%$ of the tested UPEC and APEC strains, respectively. The main function of type 1 fimbriae in E. coli pathogenesis is adhesion to the host tissue, especially in urinary tract infections (UTIs) [48-50]. Type 1 fimbriae help pathogenic bacteria to avoid host immune defenses (protection against phagocytosis) [51]. Expression of the fim $C$ gene enhances the virulence of $E$. coli, while deletion of this virulence factor could result in the loss of pathogenicity [52]. However, it has been shown that a low-level expression of the fim $C$ gene in commensal E. coli confers nonpathogenic functions [47]. The low-level expression of fim C in commensal strains could enhance their ability to persist in the digestive tract of the host by enabling avoidance of the immune defense activity by E. coli cells and maintain balance with the host immune system. Additionally, the prevalence of the kpsII gene (encoding capsular antigen) was comparable between the tested strains. The kpsII gene encodes extracellular capsules and plays a crucial role in bacterial resistance to the host immune system [53]. The prevalence of other VGs among the RepEC strains was very low in comparison with the APEC and UPEC strains. However, the other VGs detected in RepEC strains were typical of ExPEC pathotypes. The following VGs were identified among RepEC isolates: iss and traT-genes responsible for an increased survival in the serum, pap $C$-encoding a subunit of $P$ fimbriae, one of the most important virulence factors in urinary infections, $i u c D$ and fyu $A$-genes encoding siderophore systems and kpsI and kpsII—genes encoding extracellular capsules [27,54]. On the other hand, although ExPECs are pathogens, they are also a part of the normal gut microbiome, where they live as commensals, and their VG expressions are silenced [54]. As mentioned for virotyping among RepEC strains, the presence of $i u c D$, tsh, vat, cva/cvi, $s t x 2 f, h l y E$, eae, bpf, kpsIII and $r f c$ were not observed. These genes encode a number of functions (Table A3) $[27,54]$. The first seven of the aforementioned genes are connected with the pathogenesis of E. coli causing intestinal infections. As RepEC strains do not have those VGs, they may be considered as not being intestinal pathogens. The RepEC strain 209E was assigned to the phylogroup B2 (typical of pathogenic strains) with the VG score of 4 . We detected five virulence genes in the genome of the RepEC strain 305C (with ambiguous phenotypes). Based on the classification presented by Russo and Johnson [27], the RepEC strains 209E and 305C could be considered as potentially pathogenic ExPEC. Thirty percent of the tested RepEC isolates had the following genes: iss and traT (increased serum survival), fim C (type 1 fimbriae) and irp2 and fyfA (siderophores). The above set of VGs is typical of extraintestinal pathogens supporting survival in the host organism and resistance to the host immune system.

With the use of MLST (Table 1), we determined the ST of the selected RepEC strains (200E, 209E, 212E and 305C). They were typical of pathogenic E. coli strains. Strain 200E belongs to ST446 [41,42], which mainly includes the APEC strains and other ExPEC pathotypes, which are pathogenic for humans. The RepEC strain 209E was assigned to ST681, 
typical of the ExPEC strains, pathogenic for animals and humans [29,37]. Strain 212E belongs to an ST characteristic for UPEC and other extraintestinal pathogens $[29,55]$. The RepEC strain 305C was not assigned to any ST that was described before. In the literature, there is only one study available in which E. coli isolated from cold-blooded animals was analyzed using MLST [43]. One of the two E. coli strains with a multidrug resistant (MDR) phenotype isolated from reptiles in Taiwan was assigned to ST117, which includes a heterogenous group of ExPEC pathogens, while the other was assigned to an ST typical of nonpathogenic E. coli strains [43]. ST117 and ST88 have been previously reported in colistin-resistant mcr-1-positive pathogenic "zoonotic-related" E. coli [56,57].

The RAE-PFGE analysis revealed a high level of diversity in the tested E. coli strains (Figure 6). The dendrogram created showed that some of the tested RepEC strains cluster with the tested UPEC and APEC strains. The dendrogram created with the use of the RAE-PFGE analysis showed that strains: 15035.8 (UPEC) and 200E (RepEC) share some genetic material. These results may indicate that these pairs of strains share a some of genetic material and exhibit close phylogenetic relationships. All tested with RAE-PFGE strains isolated from reptiles have various genetic patterns. Strains 200E, 209E and 212E were isolated from snakes, but there are no closer genetic relationships. However, the 212E strain isolated from snakes and 305C strain isolated from turtles showed some similarities in their genetic profiles (Figure 6).

Based on these results, it is difficult to establish whether E. coli isolated from reptiles could have been derived from extraintestinal human or avian pathogenic E. coli strains during the evolutionary process or if they have been directly transferred to reptiles in the process of contamination via direct contact with wastewater. In light of the obtained results, it is clear that $E$. coli isolated from reptiles is an important target of scientific research. Developed in the system of cold-blooded animals and exposed to the activity of the reptilian immune system, RepEC may develop unique virulence traits that could pose a threat to the health of other animals and humans following any reptile-human and reptile-animal contact. The study presented here makes a contribution to the data of the genetic characteristics of RepEC strains and provides a meaningful insight that could be useful in the acquisition of knowledge of the possible routes of pathogen transmission and subsequent infections. Reptile breeders and people keeping cold-blooded animals as domestic pets should maintain a high level of personal hygiene and be aware of the potential health risk during contact with these animals.

\section{Materials and Methods}

\subsection{Bacterial Strains}

In the presented research, strains of $E$. coli $(n=72)$ were used belonging to the following groups. E. coli isolated from feces of healthy reptiles, which we referred to as Reptileassociated E. coli, RepEC $(n=24)$. Uropathogenic E. coli, UPEC $(n=24)$, isolated in Lower Silesia from urine samples (Dialab Medical Laboratory, Wrocław, Poland). The RepEC and UPEC strains are part of the collection of the Department of Microbiology of University of Wrocław, Poland (Table A1). E. coli causing systemic infections among birds (colibacillosis), referred to as Avian Pathogenic E. coli (APEC) $(n=24)$. APEC strains used in this study belong to the collection of the Department of Epizootiology and Clinic of Bird and Exotic Animals of Wrocław University of Environmental and Life Sciences, Wrocław, Poland. APEC strains were isolated from extraintestinal organs of poultry exhibiting colibacillosis, such as the liver or heart (Table A1).

We conducted a complete isolation and identification procedure for E. coli strains isolated from feces samples from reptiles. Samples of reptile feces or cloaca's swabs were collected by qualified Zoo's workers of the Zoological Garden in Wrocław, Poland. We obtained samples $(n=103)$ in transport media; after that, all samples were transferred onto Brain Heart Infusion (BHI) broth preincubated in $37^{\circ} \mathrm{C}$ and cultured on the mentioned below selective media. Since the contamination of samples, especially collected from reptile feces, could be the source of bias for the results of the subsequent phylogenetic analyses, the 
samples were cultured on appropriate, selective media: MacConkey Agar, Xylose Lysine Deoxycholate (XLD) Agar and Endo Agar. Moreover, we identified bacterial strains and confirmed that they are pure cultures with the application of the MALDI-TOF MS method.

Uropathogenic E. coli strains, UPEC $(n=24)$ strains, were obtained to study with scientific cooperation from the Dialab Medical Laboratory, Wrocław, Poland. Uropathogenic E. coli strains (UPEC strains) were identified according to the recommendations of the Centers for Disease Control and Prevention (CDC), Expert Committee on Biological Standardization World Health Organization (WHO)-Basic Laboratory Procedures in Clinical Bacteriology and the recommendations of the National Medical Microbiology Advisor and the National Center for Drug Susceptibility [58-61].

Whereas APEC strains $(n=24)$ isolated from extraintestinal organs (heart and liver) of poultry with colibacillosis were obtained to study with scientific cooperation from the Department of Epizootiology and Clinic of Bird and Exotic Animals of Wrocław University of Environmental and Life Sciences.

We also confirmed the purity of UPEC and APEC with diagnostic culture media: MacConkey Agar, XLD Agar and Endo Agar. All tested RepEC, UPEC and APEC strains were isolated and collected in Lower Silesia in the years 2010-2014 and are listed in Table A1 (Appendix A).

\subsection{Isolation and Identification of Bacterial Strains}

Isolates were identified using traditional biochemical testing and mass spectrometry [37]. Bacterial strains used in this study were identified as E. coli species using Bruker MALDI-TOF MS systems. All analyses were performed with the AUTOFLEX III SmartBeam (Bruker Daltonics, Bremen, Germany) and UltraflExtreme (Bruker Daltonics, Bremen, Germany) using the Biotyper 3.0 software consisting of a database containing 4613 entries. Identification by MALDI-TOF MS was confirmed by multiple tests. Identification of isolates at species level with $\log$ scores $\geq 2.300$ was considered highly probable. Log scores $>2.0$ indicated a high probability of identification at the species level. Log scores between 1.700-1.999 yielded probable identification at the genus level. Scores $<1.800$ were interpreted as unreliable identification.

\subsection{DNA Extraction}

Whole-genome DNA were extracted from all tested bacterial strains $(n=72)$ with the application of a commercial versatile kit for genomic DNA purification (Genomic Mini, AA-Biotechnology, Gdynia, Poland) and stored in $-20^{\circ} \mathrm{C}$.

\subsection{Phylogenetic Groups of E. coli}

In order to assess the genetic diversity, phylogenetic groups of the tested E. coli strains were determined by a quadruplex-PCR method [23], with primers targeting the genes $c h u A$ (288 bp), yjaA (211 bp), arpA (400 bp) and a genetic region with an unknown function, TspE4C2 (152 bp). In the case of nonconclusive results, for strains belonging to groups $\mathrm{D} / \mathrm{E}$ or A/C, the PCR reaction was performed to detect the $\operatorname{arp} A(301 \mathrm{bp})$ and $\operatorname{trp} A(219 \mathrm{bp}$ ) genes.

For the reaction, there was set up $25 \mu \mathrm{l}$ of PCR mixture per sample containing $50 \mathrm{ng}$ of template DNA, 2-U Taq polymerase DNA DreamTaq ${ }^{\mathrm{TM}}$ Green (Thermo Scientific, Vilnius, Lithuania), $2.5 \mu \mathrm{L}$ of $10 \times$ DNA DreamTaq ${ }^{\mathrm{TM}}$ Green Buffer (Thermo Scientific, Vilnius, Lithuania), 200-mM dNTP (Thermo Scientific, Vilnius, Lithuania) and 20 pmol each of the primers (Genomed, Warszawa, Poland). PCR amplifications were performed with parameters as follows: $95^{\circ} \mathrm{C}$ for $4 \mathrm{~min}$ and 30 cycles of denaturation $\left(30 \mathrm{~s}, 95^{\circ} \mathrm{C}\right)$, annealing (20 s, $59^{\circ} \mathrm{C}$ for quadruplex and phylogroup $\mathrm{C}$ and $20 \mathrm{~s}, 57^{\circ} \mathrm{C}$ for phylogroup E), extension steps $\left(1 \mathrm{~min}, 72^{\circ} \mathrm{C}\right)$ and final extension $\left(10 \mathrm{~min}, 68^{\circ} \mathrm{C}\right)$. The list of the primers (Genomed, Warszawa, Poland) used for the determination of the phylogenetic groups of $E$. coli is presented in Table A2 (Appendix A). 


\subsection{Virulence Genotyping}

All E. coli strains were tested for $19 \mathrm{VGs}$, including those related to the pathogenicity of diarrhoeagenic E. coli (astA, stx2, eae and bfp); pathogenicity of APEC (iss, irp2, iucD, tsh, vat, fyuA, hlyE, fimC and cvi/cva) and genes characteristic for UPEC (papC, kpsMTII, kpsMT (K1), kpsMTI, rfc and traT) (see Table A3 for more details). These 19 VGs were targeted by three multiplex-PCR reactions according to the literature $[38,62,63]$. The list of primers used in the determination of VGs in E. coli (Genomed, Warszawa, Poland) is presented in Table A3 (Appendix A).

On the basis of the PCR results obtained, the percentage values for VG prevalence were assigned to the categories of very low, low, medium, high or very high frequencies, as presented in Table 2.

Table 2. Frequency of virulence genes (VGs) occurrence scale.

\begin{tabular}{cc}
\hline Percentage Prevalence of VGs & Frequency of VGs \\
\hline $0-10 \%$ & Very low \\
$11-20 \%$ & Low \\
$21-45 \%$ & Medium \\
$46-80 \%$ & High \\
$81-100 \%$ & Very high \\
\hline
\end{tabular}

\subsection{Gel Electrophoresis of PCR Amplification Products}

All PCRs reactions were conducted in a DNA Thermal Cycler T100 ${ }^{\mathrm{TM}}$ (Bio-Rad, Dublin, Ireland). Amplified products were resolved on a $2 \%$ agarose gel (Sigma-Aldrich, Wien, Switzerland) and visualized using Midori Green DNA (Nippon Genetics, Dueren, Germany). Band patterns were visualized under UV light and photographed using a Gel Doc camera system (Bio-Rad) and analyzed with Quantity One software (Bio-Rad). For each PCR reaction, $1 \mu \mathrm{l}$ of sterile water added to the PCR mixture used as a negative control in the experiment. PCR assays were performed twice to ensure that the strains were correctly assigned to their respective patterns.

For the purpose of the next step of the phylogenetic analyses (RAE-PFGE analysis and MLST), eleven of the tested E. coli strains were selected: UPEC 15279.21, 1119 and 15035.8; APEC 1288, 1239, 189A and 60C and RepEC 200E, 209E, 212E and 305C. These strains were selected based on the obtained results of phylogroup assignment and virotyping.

\subsection{Restriction Analysis Combined with Pulsed-Field Gel Electrophoresis (RAE-PFGE)}

The above-mentioned eleven $E$. coli strains were fingerprinted by using the RAE-PFGE method, as per the PulseNet protocol developed by the US Centers for Diseases Control and Prevention [64] (PulseNet). Total DNA was prepared for restriction analysis with the application of the XbaI enzyme (Thermo Fisher Scientific, Vilnius, Lithuania). DNA separation was performed with CHEF DR III (Bio-Rad) under the following conditions: $1 \%$ agarose gel (Prona Agarose) in 0.5-M Tris-Borate-EDTA buffer at $14^{\circ} \mathrm{C}$ for $19 \mathrm{~h}$ at $6.0 \mathrm{~V} / \mathrm{cm}$ $(200 \mathrm{~V})$. Pulse time ranged between 2.2 and 63.8 s. Molecular weight marker ProMegaMarkers ${ }^{\circledR}$ Lambda Ladders was used for analysis (Promega, Madison, WI, USA). The gels were stained and visualized as per the PCR reactions above. RAE-PFGE patterns were analyzed by visual assessment, and the dendrograms were generated with the UPGMA method using online software available at http://insilico.ehu.es/.

\subsection{Genetic Population Structure Analysis of E. coli Strains by Multi-Locus Sequence Typing}

MLST analysis of the E. coli strains selected $(n=11)$ previously was carried out by using the MLST scheme for E. coli developed by Achtman et al. [12,29]. Housekeeping genes, their biological functions and the sequences of the applied primers are presented in Table A4 (Appendix A). Presence of the correct size PCR product was confirmed by agarose gel electrophoresis, as above, using an appropriate DNA marker (100-bp ladder; SigmaAldrich). DNA samples were prepared and sequenced by LGC Standards (Manchester, 
UK), and the obtained sequences were analyzed with CLC Genomics Workbench. The determined allelotypes of the tested E. coli strains were assigned to the relevant Sequence Type (ST) according to the http:/ / enterobase.warwick.ac.uk/species/index/ecoli database.

Author Contributions: Conceptualization: M.K. (Marta Książczyk), B.D., M.K. (Maciej Kuczkowski), A.W. (Alina Wieliczko) and G.B.-P.; data curation: M.K. (Marta Książczyk), A.K.-K. and G.B.-P.; formal analysis: M.K. (Marta Książczyk), B.D., M.K. (Maciej Kuczkowski), A.W. (Anna Wzorek) and G.B.-P.; funding acquisition: M.K. (Marta Książczyk) and G.B.-P.; investigation, M.K. (Marta Książczyk), B.D., M.K. (Maciej Kuczkowski), R.O., A.W. (Anna Wzorek) and A.K.-K.; methodology: M.K. (Marta Książczyk), B.D., M.K. (Maciej Kuczkowski), R.O., A.W. (Anna Wzorek), M.U., Mathew Upton, A.K.-K., K.K., R.R., A.W. (Alina Wieliczko) and G.B.-P.; project administration: M.K. (Marta Książczyk) and G.B.-P.; resources, M.K. (Marta Książczyk), B.D., M.K. (Maciej Kuczkowski), K.K., M.U., Mathew Upton, A.K.-K., R.R., A.W. (Alina Wieliczko) and G.B.-P.; supervision: M.K. (Maciej Kuczkowski), A.W. (Alina Wieliczko) and G.B.-P.; validation: M.K. (Marta Książczyk), B.D., M.K. (Maciej Kuczkowski), A.W. (Anna Wzorek), M.U., Mathew Upton, A.K.-K., R.R., A.W. (Alina Wieliczko) and G.B.-P.; Writing-Original draft: M.K. (Marta Książczyk), B.D., M.K. (Maciej Kuczkowski), R.O., M.U., Mathew Upton, A.K.-K., A.J. and A.W. (Alina Wieliczko) and Writing-Review and editing: M.K. (Marta Książczyk), B.D., M.K. (Maciej Kuczkowski), R.O., K.K., A.W. (Anna Wzorek), M.U., Mathew Upton, A.K.-K., A.J., R.R., A.W. (Alina Wieliczko) and G.B.-P. All authors have read and agreed to the published version of the manuscript.

Funding: The project was financed from the National Science Centre, Grant No. NCN UMO/2015/17/N/ NZ9/00977, Publication of this article was financially supported by the Excellence Initiative - Research University (IDUB) programme for the University of Wroclaw.

Institutional Review Board Statement: Not applicable.

Informed Consent Statement: Not applicable.

Data Availability Statement: The data presented in this study are available on request from the corresponding author. The data are not publicly available.

Acknowledgments: The authors wish to thank Marek Pastuszek for his help in collecting materials from the reptiles, Emil Paluch for his contribution to the preliminary studies and the Dialab Laboratory (Wrocław, Poland) for providing the E. coli strains.

Conflicts of Interest: The authors declare no conflict of interest.

\section{Appendix A}

Table A1. The list of Escherichia coli strains: RepEC $(n=24)$ UPEC $(n=24)$ and APEC $(n=24)$ used in the study.

\begin{tabular}{|c|c|c|c|c|c|}
\hline & \multicolumn{4}{|c|}{ Group of Escherichia coli Strains } & APEC \\
\hline \multirow[t]{2}{*}{ Strain Code } & Source of Isolated Bacteria & Strain Code & Source of Isolated Bacteria & Strain Code & Source of Isolated Bacteria \\
\hline & $\begin{array}{c}\text { Escherichia coli strains } \\
\text { isolated from feces of } \\
\text { reptiles (snakes, lizards and } \\
\text { turtles) }\end{array}$ & & $\begin{array}{l}\text { Escherichia coli isolated from } \\
\text { urine samples of patients } \\
\text { with symptomatic and } \\
\text { asymptomatic urinary tract } \\
\text { infections }\end{array}$ & & $\begin{array}{c}\text { Escherichia coli strains } \\
\text { isolated from extraintestinal } \\
\text { organs (heart, liver) of } \\
\text { poultry with colibacillosis }\end{array}$ \\
\hline $200 \mathrm{E}$ & $\begin{array}{l}\text { Snake (Lamprophis } \\
\text { fuliginosus) }\end{array}$ & 15641.38 & & $46 \mathrm{~A}$ & \\
\hline $201 \mathrm{E}$ & $\begin{array}{c}\text { Snake (Orthriophis } \\
\text { taeniurus) }\end{array}$ & 15514.33 & & 1316 & \\
\hline $203 E$ & Lizard (Pogona vitticeps) & 15165.15 & & 1422B & \\
\hline $204 \mathrm{E}$ & $\begin{array}{c}\text { Lizard (Chamaeleo } \\
\text { calyptratus) }\end{array}$ & 15279.21 & & $1442 \mathrm{~A}$ & \\
\hline $205 E$ & Lizard (Anolis barbatus) & 15988.54 & & 1288 & \\
\hline $206 \mathrm{E}$ & Snake (Epicrates cenchria) & 15300.22 & & $189 \mathrm{~A}$ & \\
\hline
\end{tabular}


Table A1. Cont.

\begin{tabular}{|c|c|c|c|c|c|}
\hline \multicolumn{6}{|c|}{ Group of Escherichia coli Strains } \\
\hline \multicolumn{2}{|r|}{ RepEC } & \multicolumn{2}{|c|}{ UPEC } & \multicolumn{2}{|r|}{ APEC } \\
\hline Strain Code & Source of Isolated Bacteria & Strain Code & Source of Isolated Bacteria & Strain Code & Source of Isolated Bacteria \\
\hline 207E & $\begin{array}{l}\text { Snake (Lamprophis } \\
\text { fuliginosus) }\end{array}$ & 15593.39 & & $36 \mathrm{C}$ & \\
\hline $208 \mathrm{E}$ & $\begin{array}{l}\text { Snake (Lamprophis } \\
\text { fuliginosus) }\end{array}$ & 15159.19 & & 1453 & \\
\hline $209 E^{*}$ & $\begin{array}{l}\text { Snake (Lamprophis } \\
\text { fuliginosus) }\end{array}$ & 15607.35 & & $172 \mathrm{~A}$ & \\
\hline $210 \mathrm{E}$ & Snake (Lampropeltisgetula) & 15992.42 & & 188 & \\
\hline $211 \mathrm{E}$ & Snake (Elaphe schrencki) & 15997.9 & & 1410 & \\
\hline $212 \mathrm{E}$ & Snake (Coelognathus radiata) & 15550.25 & & 1451 & \\
\hline $305 \mathrm{C}$ & Turtle (Kinixys belliana) & 15589.37 & & $1251 \mathrm{~B}$ & \\
\hline $213 \mathrm{E}$ & Turtle (Chelonoidis nigra) & 1110 & & 06B & \\
\hline $220 \mathrm{E}$ & Turtle (Geochelone platynota) & 15599.34 & & $1386 \mathrm{C}$ & \\
\hline $222 \mathrm{E}$ & Turtle (Testudo marginata) & 15067.4 & & $17 \mathrm{~A}$ & \\
\hline $226 \mathrm{E}$ & $\begin{array}{l}\text { Lizard (Chamaeleo } \\
\text { calyptratus) }\end{array}$ & 15059.6 & & $60 \mathrm{C}$ & \\
\hline $228 \mathrm{E}$ & Turtle (Geochelone platynota) & 15320.27 & & 240 & \\
\hline $229 \mathrm{E}$ & Turtle (Astrochelysradiata) & 15038.2 & & $73 \mathrm{C}$ & \\
\hline $230 \mathrm{E}$ & Turtle (Centrochelys sulcata) & 1119 & & $010 \mathrm{~A}$ & \\
\hline $234 \mathrm{E}$ & Turtle (Testudo horsfieldii) & 15611.41 & & 169 & \\
\hline $239 \mathrm{E}$ & $\begin{array}{c}\text { Snake (Lampropeltis } \\
\text { triangulum) }\end{array}$ & 15155.16 & & 1216 & \\
\hline $240 \mathrm{E}$ & Lizard (Anolis baracoae) & 15035.8 & & 1326B & \\
\hline $241 \mathrm{E}$ & Turtle (Chelonoidisnigra) & 15084.1 & & 1239 & \\
\hline
\end{tabular}

Table A2. The list of the primers (Genomed, Gdynia, Poland) used for the determination of the phylogenetic groups of $E$. coli in the quadruplex-PCR method $[15,18]$.

\begin{tabular}{|c|c|c|c|}
\hline Gene & Sequences of Primers & PCR Product Size (bp) & Gene Bank ID \\
\hline yjaA & 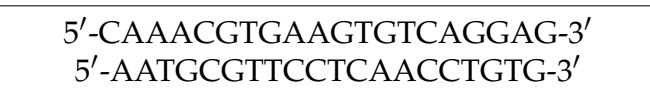 & 288 & 948515 \\
\hline chuA & $\begin{array}{l}\text { 5'-CAAACGTGAAGTGTCAGGAG-3' } \\
\text { 5'-AATGCGTTCCTCAACCTGTG-3' }\end{array}$ & 211 & 7155958 \\
\hline TspE4C2 & $\begin{array}{l}5^{\prime} \text {-CACTATTCGTAAGGTCATCC-3' } \\
5^{\prime} \text {-AGTTTATCGCTGCGGGTCGC-3' }\end{array}$ & 152 & EU240725.1 \\
\hline $\operatorname{arp} A$ & $\begin{array}{l}5^{\prime}-\text { AACGCTATTCGCCAGCTTGC-3' } \\
5^{\prime} \text {-TCTCCCCATACCGTACGCTA-3' }\end{array}$ & 400 & 7155679 \\
\hline $\operatorname{arp} A$ & $\begin{array}{c}\text { 5'-GATTCCATCTTGTCAAAATATGCC-3' } \\
\text { 5'-GAAAAGAAAAAGAATTCCCAAGAG-3' }\end{array}$ & 301 & 944933 \\
\hline $\operatorname{trp} A$ & $\begin{array}{c}\text { 5'-AGTTTTATGCCCAGTGCGAG-3' } \\
\text { 5'-TCTGCGCCGGTCACGCCC-3' }\end{array}$ & 219 & 912862 \\
\hline $\operatorname{trp} A$ & $\begin{array}{l}5^{\prime} \text {-CGGCGATAAAGACATCTTCAC-3' } \\
5^{\prime} \text {-GCAACGCGGCCTGGCGGAAG-3' }\end{array}$ & 489 & 13702525 \\
\hline
\end{tabular}

Table A3. The list of the primers (Genomed, Gdynia, Poland) used for the virotyping of the E. coli strains.

\begin{tabular}{|c|c|c|c|c|}
\hline Gene & Sequences of Primers & $\begin{array}{l}\text { PCR Product } \\
\text { Size (bp) }\end{array}$ & Gene Bank ID & Biological (Enzymatic) Function \\
\hline ast $A$ & $\begin{array}{c}5^{\prime}-\text { CCATCAACACA-3' }^{\prime} \\
5^{\prime}-\text { TCAGGTCGCGAGTG-3' }^{\prime}\end{array}$ & 116 & AF143819 & $\begin{array}{l}\text { Gene encoding heat-stable toxin } 1 \\
\text { (ST1) }\end{array}$ \\
\hline Iss & $\begin{array}{l}5^{\prime} \text {-ATCACATAGGATTCTGCCG-3' } \\
5^{\prime} \text {-CAGCGGAGTATAGATGCCA-3' }\end{array}$ & 309 & X52665 & $\begin{array}{l}\text { Gene encoding outer membrane } \\
\text { protein of increased serum survival }\end{array}$ \\
\hline $\operatorname{irp} 2$ & $\begin{array}{l}5^{\prime} \text {-GGATTCGCTGTTACCGGAC3 }{ }^{\prime} \\
5^{\prime} \text {-AACTCCTGATACAGGTGGC-3' }\end{array}$ & 413 & L18881 & Gene encoding iron binding protein \\
\hline$i u c D$ & $\begin{array}{c}5^{\prime} \text {-ACAAAAAGTTCTATCGCTTCC-3' } \\
5^{\prime} \text {-CCTGATCCAGATGATGCTC- } 3^{\prime}\end{array}$ & 714 & M18968 & $\begin{array}{l}\text { Gene encoding siderophore's } \\
\text { complex }\end{array}$ \\
\hline tsh & $\begin{array}{c}5^{\prime} \text {-ACTATTCTCTGCAGGAAGTC-3' } \\
5^{\prime} \text {-TTCCGATGTTCTGAA-3' }\end{array}$ & 824 & AF218073 & $\begin{array}{l}\text { Gene encoding thermolabile } \\
\text { haemagglutinin }\end{array}$ \\
\hline vat & $\begin{array}{c}5^{\prime} \text {-TCCTGGGACATAATGGTCAG-3' } \\
5^{\prime} \text { - GTGTCAGAACGGAATTGT-3' }\end{array}$ & 981 & AY151282 & $\begin{array}{l}\text { Gene encoding vacuolating } \\
\text { autotransporter toxin }\end{array}$ \\
\hline
\end{tabular}


Table A3. Cont.

\begin{tabular}{|c|c|c|c|c|}
\hline Gene & Sequences of Primers & $\begin{array}{l}\text { PCR Product } \\
\text { Size (bp) }\end{array}$ & Gene Bank ID & Biological (Enzymatic) Function \\
\hline fyuA & $\begin{array}{l}\text { 5'-TGATTAACCCCGCGACGGGAA-3' } \\
\text { 5'-CGCAGTAGGCACGATGTTGTA-3' }\end{array}$ & 880 & Z38064 & $\begin{array}{l}\text { Gene belonging to the operon } \\
\text { encoding aerobactin siderophore } \\
\text { complex at the plasmid ColV-K30 }\end{array}$ \\
\hline st $x 2 f$ & $\begin{array}{l}\text { 5'-ATCCTATTCCCGGGAGTTTACG-3' } \\
\text { 5'-GCGTCATCGTATACACAGGAGC-3' }^{\prime}\end{array}$ & 338 & 912579 & Gene encoding Shiga like toxin \\
\hline hlyE & $\begin{array}{c}\text { 5'-GGTGCAGCAGAAAAAGTTGTAG-3' } \\
\text { 5'-TCTCGCCTGATAGTGTTTGGTA-3' }^{\prime}\end{array}$ & 569 & 13701006 & Gene encoding haemolysin \\
\hline fim $C$ & $\begin{array}{l}\text { 5'-GTTGATCAAACCGTTCAG-3' } \\
\text { 5'-AATAACGCGCCTGGAACG-3' }\end{array}$ & 424 & 948843 & Gene encoding fimbriae type I \\
\hline eae & $\begin{array}{l}\text { 5'-TCAATGCAGTTCCGTTATCAGTT-3' } \\
\text { 5'-GTAAAGTCCGTTACCCCAACCTG-3' }\end{array}$ & 482 & AF022236 & Gene encoding intimin \\
\hline$b f p$ & $\begin{array}{l}5^{\prime} \text {-GGAAGTCAAATTCATGGGGGTAT-3' } \\
5^{\prime} \text {-GGAATCAGACGCAGACTGGTAGT } 3^{\prime}\end{array}$ & 246 & KJ020697 & Gene encoding bundle forming pilli \\
\hline$c v i / c v a$ & $\begin{array}{l}\text { 5'-TGGTAGAATGTGCCAGAGCAAG-3' } \\
\text { 5'-GAGCTGTTTGTAGCGAAGCC-3' }\end{array}$ & 1181 & AJ223631 & $\begin{array}{l}\text { Gene encoding colicin at the ColV } \\
\text { plasmid }\end{array}$ \\
\hline papC & $\begin{array}{l}\text { 5'-GTGGCAGTATGAGTAATGACCGTTA-3' } \\
\text { 5'-ATATCCTTTCTGCAGGGATGCAATA-3' }^{\prime}\end{array}$ & 200 & X61239 & Gene encoding P fimbriae subunit \\
\hline kpsMTII & $\begin{array}{c}\text { 5'-GCGCATTTGCTGATACTGTTG-3' } \\
\text { 5'-CATCCAGACGATAAGCATGAGCA-3' }\end{array}$ & 272 & X53819 & $\begin{array}{l}\text { Gene encoding extracellular capsules } \\
\text { type II biosynthesis proteins }\end{array}$ \\
\hline $\begin{array}{l}\text { kpsMT } \\
(\text { K1) }\end{array}$ & $\begin{array}{c}\text { 5'-TAGCAAACGTTCTATTGGTGC-3' } \\
\text { 5'-CATCCAGACGATAAGCATGAGCA-3' }\end{array}$ & 153 & M57382 & Gene encoding capsules antigen K1 \\
\hline kpsMTIII & $\begin{array}{l}\text { 5'-TCCTCTTGCTACTATTCCCCCT -3' } \\
5^{\prime} \text {-AGGCGTATCCATCCCTCCTAAC-3' }\end{array}$ & 392 & AF007777 & $\begin{array}{l}\text { Gene encoding extracellular capsules } \\
\text { type III biosynthesis proteins }\end{array}$ \\
\hline$r f \mathcal{C}$ & $\begin{array}{l}\text { 5'-ATCCATCAGGAGGGGACTGGA-3' } \\
5^{\prime} \text {-AACCATACCAACCAATGCGAG -3' }\end{array}$ & 788 & U39042 & $\begin{array}{l}\text { Gene encoding O-side-chain antigen } \\
\text { of LPS }\end{array}$ \\
\hline traT & $\begin{array}{l}\text { 5'-GGTGTGGTGCGATGAGCACAG-3' } \\
\text { 5'-CACGGTTCAGCCATCCCTGAG-3' }^{\prime}\end{array}$ & 290 & J01769 & $\begin{array}{l}\text { Gene encoding serum resistance and } \\
\text { pathogenicity-related protein }\end{array}$ \\
\hline
\end{tabular}

Table A4. Oligonucleotides used in the MLST method, their size and Gene Bank ID.

\begin{tabular}{|c|c|c|c|}
\hline Gene & Primer's Sequences & PCR Product Size (bp) & $\begin{array}{l}\text { Biological (Enzymatic) } \\
\text { Function }\end{array}$ \\
\hline$a d k$ & $\begin{array}{l}\text { 5'-ATTCTGCTTGGCGCTCCGGG-3' } \\
\text { 5'-CCGTCAACTTTCGCGTATTT-3' }\end{array}$ & 583 & adenylate kinase \\
\hline fumC & $\begin{array}{l}\text { 5'-TCACAGGTCGCCAGCGCTTC-3' } \\
\text { 5'-GTACGCAGCGAAAAAGATTC-3' }\end{array}$ & 806 & fumarate hydratase \\
\hline gyrB & $\begin{array}{l}\text { 5'-TCGGCGACACGGATGACGGC-3' } \\
\text { 5'-GTCCATGTAGGCGTTCAGGG-3' }\end{array}$ & 911 & DNA gyrase \\
\hline$i c d$ & $\begin{array}{c}\text { 5'-ATGGAAAGTAAAGTAGTTGTTCCGGCACA-3' } \\
\text { 5'-GGACGCAGCAGGATCTGTT-3' }\end{array}$ & 878 & isocitrate dehydrogenase \\
\hline$m d h$ & $\begin{array}{l}\text { 5'-AGCGCGTTCTGTTCAAATGC-3' } \\
\text { 5'-CAGGTTCAGAACTCTCTCTGT-3' }\end{array}$ & 932 & malate dehydrogenase \\
\hline purA & $\begin{array}{l}\text { 5'-CGCGCTGATGAAAGAGATGA-3' } \\
\text { 5'-CATACGGTAAGCCACGCAGA-3' }\end{array}$ & 816 & adenylosuccinate synthetase \\
\hline $\operatorname{rec} A$ & $\begin{array}{c}\text { 5'-ACCTTTGTAGCTGTACCACG-3' } \\
\text { 5'-TCGTCGAAATCTACGGACCGGA-3' }\end{array}$ & 780 & ATP/GTP binding motif \\
\hline
\end{tabular}


A.

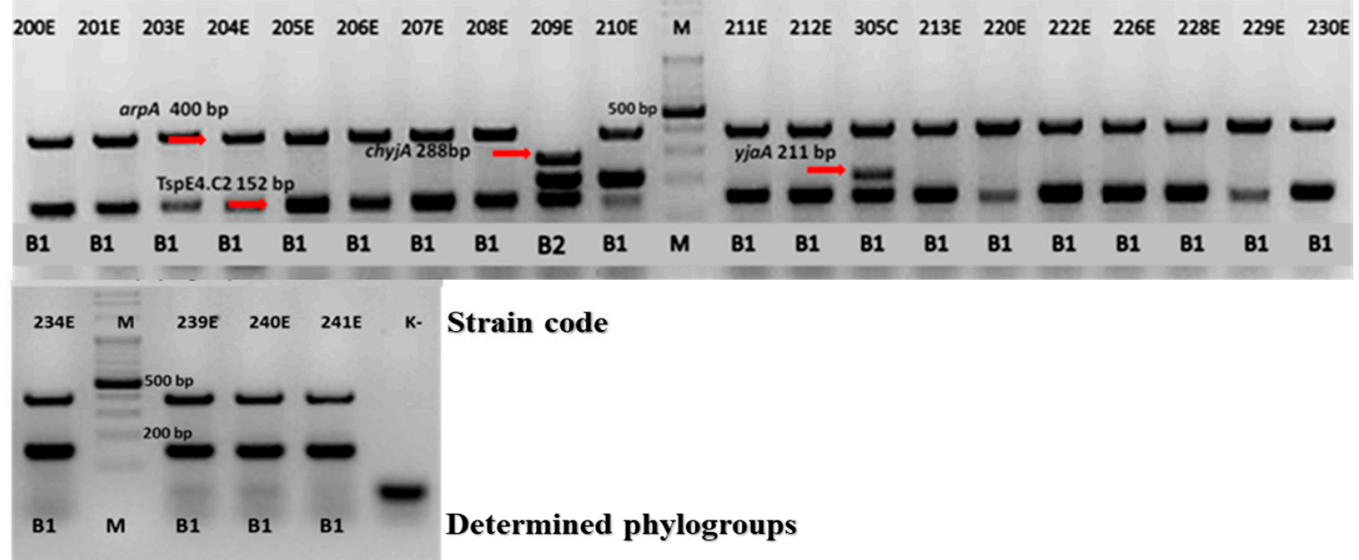

\begin{tabular}{|c|c|c|c|c|c|c|c|}
\hline \multirow{2}{*}{$\begin{array}{l}\text { E. coli } \\
\text { strain }\end{array}$} & \multicolumn{6}{|c|}{ Genes amplified in quadruplex $P C R$ reaction } & \multirow{2}{*}{$\begin{array}{l}\text { Assigned } \\
\text { phylogroup }\end{array}$} \\
\hline & chuA & $y j a A$ & TspE4.C2 & $\operatorname{arp} A$ & $\operatorname{arp} A$ gr. $\mathrm{E}$ & $\operatorname{trp} A$ gr.C & \\
\hline $200 \mathrm{E}$ & - & - & + & + & nd & nd & B1 \\
\hline $201 \mathrm{E}$ & - & - & + & + & nd & nd & B1 \\
\hline $203 E$ & - & - & + & + & nd & nd & B1 \\
\hline $204 \mathrm{E}$ & - & - & + & + & nd & nd & B1 \\
\hline $205 \mathrm{E}$ & - & - & + & + & nd & nd & B1 \\
\hline $206 \mathrm{E}$ & - & - & + & + & nd & nd & B1 \\
\hline $207 \mathrm{E}$ & - & - & + & + & nd & nd & B1 \\
\hline $208 \mathrm{E}$ & - & - & + & + & nd & nd & B1 \\
\hline $209 \mathrm{E}$ & + & + & + & - & nd & nd & B2 \\
\hline $210 \mathrm{E}$ & - & + & + & + & nd & nd & B1 \\
\hline $211 \mathrm{E}$ & - & - & + & + & nd & nd & B1 \\
\hline $212 \mathrm{E}$ & - & - & + & + & nd & nd & B1 \\
\hline $305 C$ & - & - & + & + & nd & nd & B1 \\
\hline $213 \mathrm{E}$ & - & - & + & + & nd & nd & B1 \\
\hline $220 \mathrm{E}$ & - & - & + & + & nd & nd & B1 \\
\hline $222 \mathrm{E}$ & - & - & + & + & nd & nd & B1 \\
\hline $226 \mathrm{E}$ & - & - & + & + & nd & nd & B1 \\
\hline $228 \mathrm{E}$ & - & - & + & + & nd & nd & B1 \\
\hline $229 \mathrm{E}$ & - & - & + & + & nd & nd & B1 \\
\hline $230 \mathrm{E}$ & - & - & + & + & nd & nd & B1 \\
\hline $234 \mathrm{E}$ & - & - & + & + & nd & nd & B1 \\
\hline $239 \mathrm{E}$ & - & - & + & + & nd & nd & B1 \\
\hline $240 \mathrm{E}$ & - & - & + & + & nd & nd & B1 \\
\hline $241 \mathrm{E}$ & - & - & + & + & nd & nd & B1 \\
\hline
\end{tabular}

B.

Figure A1. (A) Electrophoretograms of amplified products of the quadruplex-PCR method $[15,18]$ with primers targeting Table 288. bp), yjaA (211 bp), arpA (400 bp) and a genetic region with an unknown function: TspE4C2 (152 bp) conducted for the $\operatorname{RepEC}(n=24)$-tested strains. (B) Assignation of $\operatorname{RepEC}(n=24)$ strains to the phylogroups. M-DNA mass marker. 


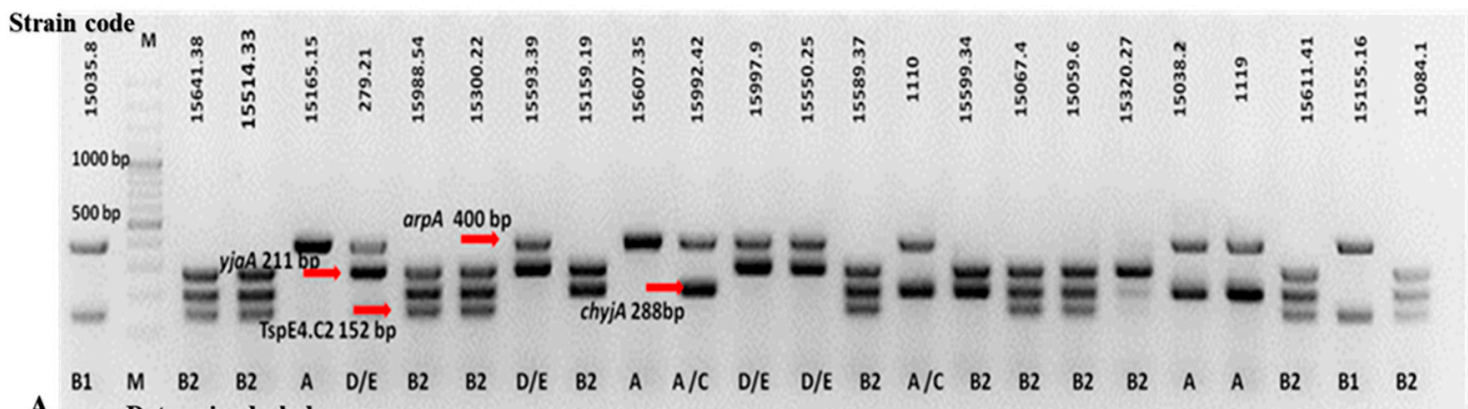

A. Determined phylogroups

\begin{tabular}{lllllll}
\hline \multirow{2}{*}{$\begin{array}{l}\text { E. coli } \\
\text { strain }\end{array}$} & \multicolumn{4}{c}{ Genes amplified in quadruplexPCR reaction } & $\begin{array}{c}\text { Assigned } \\
\text { phylogroup }\end{array}$ \\
\cline { 2 - 6 } & chuA & yjaA & TspE4.C2 & arpA & $\operatorname{arpA}$ gr.E & trpA gr.C
\end{tabular}

\begin{tabular}{|c|c|c|c|c|c|c|c|}
\hline 15641.38 & + & + & + & - & nd & nd & B2 \\
\hline 15514.33 & + & + & + & - & nd & nd & B2 \\
\hline 15165.15 & - & - & - & + & nd & nd & A \\
\hline 15279.21 & + & - & + & + & nd & - & $\mathrm{D}$ \\
\hline 15988.54 & + & + & + & - & nd & nd & B2 \\
\hline 15300.22 & + & + & + & - & nd & nd & B2 \\
\hline 15593.39 & + & - & - & + & + & nd & E \\
\hline 15159.19 & + & + & - & - & nd & nd & B2 \\
\hline 15607.35 & - & - & - & + & nd & nd & A \\
\hline 15992.42 & - & + & - & + & nd & + & C \\
\hline 15997.9 & + & - & - & + & + & nd & E \\
\hline 15550.25 & + & - & - & + & + & nd & E \\
\hline 15589.37 & + & + & + & - & nd & nd & B2 \\
\hline 1110 & - & + & - & + & nd & + & C \\
\hline 15599.34 & + & + & - & - & nd & nd & B2 \\
\hline 15067.4 & + & + & + & - & nd & nd & B2 \\
\hline 15059.6 & + & + & + & - & nd & nd & B2 \\
\hline 15320.27 & + & + & - & - & nd & nd & B2 \\
\hline 15038.2 & - & + & - & + & nd & + & C \\
\hline 1119 & - & + & - & + & nd & + & C \\
\hline 15611.41 & + & + & + & - & nd & nd & B2 \\
\hline 15155.16 & - & - & + & + & nd & nd & B1 \\
\hline 15035.8 & - & - & + & + & nd & nd & B1 \\
\hline 15084.1 & + & + & + & - & nd & nd & B2 \\
\hline
\end{tabular}

B.

Figure A2. (A) Electrophoretograms of amplified products of the quadruplex-PCR method $[15,18]$ with primers targeting the genes: chuA (288 bp), yjaA (211 bp), arpA (400 bp) and a genetic region with an unknown function: TspE4C2 (152 bp) conducted for the UPEC-tested strains $(n=24)$. (B) Assignation of UPEC strains $(n=24)$ to the phylogroups. M-DNA mass marker. 


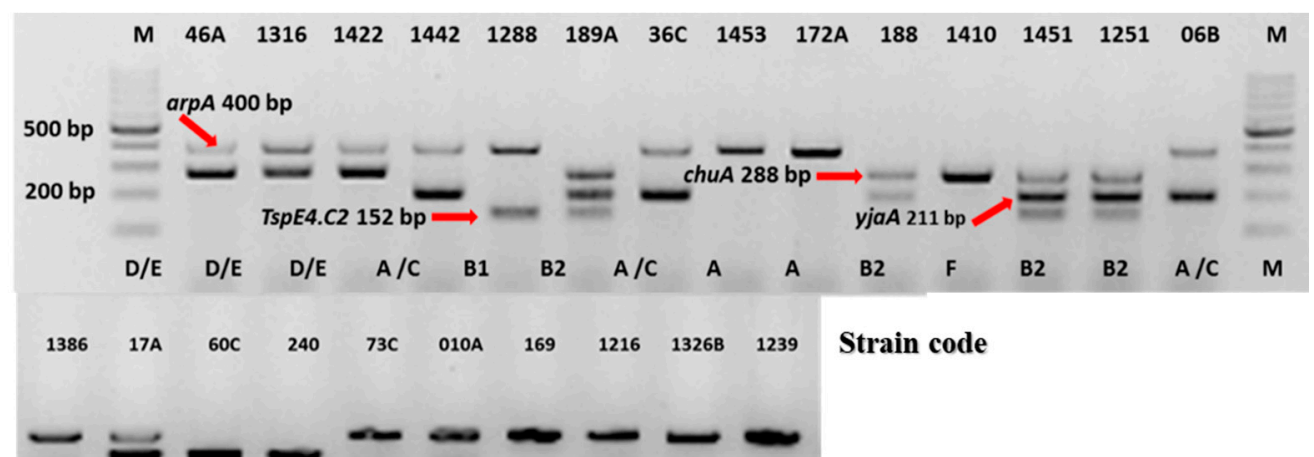

A.

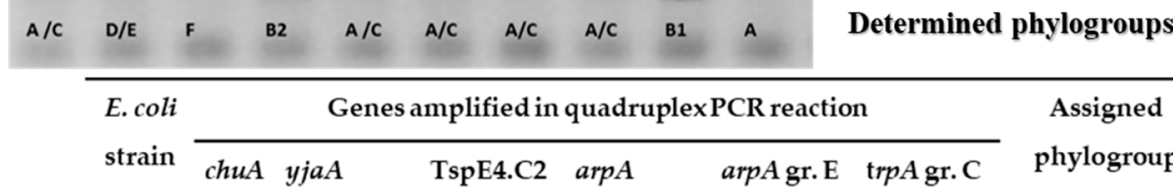

\begin{tabular}{|c|c|c|c|c|c|c|c|}
\hline $46 \mathrm{~A}$ & + & - & - & + & + & nd & $\bar{E}$ \\
\hline 1316 & + & - & - & + & + & nd & E \\
\hline $1422 B$ & + & - & - & + & + & nd & E \\
\hline $1442 \mathrm{~A}$ & - & + & - & + & nd & nd & C \\
\hline 1288 & - & - & + & + & nd & nd & B1 \\
\hline $189 \mathrm{~A}$ & + & + & + & - & nd & nd & B2 \\
\hline $36 \mathrm{C}$ & - & + & - & + & nd & + & C \\
\hline 1453 & - & - & - & + & nd & nd & A \\
\hline $172 \mathrm{~A}$ & - & - & - & + & nd & nd & A \\
\hline 188 & + & + & - & - & nd & nd & B2 \\
\hline 1410 & + & - & - & - & nd & nd & $\mathrm{F}$ \\
\hline 1451 & + & + & + & - & nd & nd & B2 \\
\hline $1251 \mathrm{~B}$ & + & + & + & - & nd & nd & B2 \\
\hline 06B & - & + & - & + & nd & + & C \\
\hline 1386 & - & + & - & + & nd & + & C \\
\hline $17 \mathrm{C}$ & + & - & - & + & nd & nd & E \\
\hline $37 \mathrm{C}$ & + & - & - & - & nd & nd & $\mathrm{F}$ \\
\hline 1461 & + & + & + & - & nd & nd & B2 \\
\hline $73 C$ & - & + & - & + & nd & + & C \\
\hline $010 \mathrm{~A}$ & - & + & - & + & nd & + & C \\
\hline 169 & - & - & - & + & nd & - & A \\
\hline 1216 & - & + & - & + & nd & + & C \\
\hline 1326B & - & - & + & + & nd & nd & B1 \\
\hline 1239 & - & - & - & + & + & nd & E \\
\hline 09B & + & - & - & - & nd & + & $\mathrm{F}$ \\
\hline 1456 & + & + & + & - & nd & nd & B2 \\
\hline $60 \mathrm{C}$ & + & - & - & + & nd & nd & $\mathrm{F}$ \\
\hline $240 \mathrm{~A}$ & + & + & + & + & nd & nd & $\mathrm{B} 2$ \\
\hline
\end{tabular}

\section{B.}

Figure A3. (A) Electrophoretograms of amplified products of the quadruplex-PCR method $[15,18]$ with primers targeting the genes: chuA (288 bp), yjaA (211 bp), arpA (400 bp) and genetic region with an unknown function: TspE4C2 (152 bp) conducted for the APEC-tested strains $(n=24)$. (B) Assignation of APEC strains $(n=24)$ to the phylogroup. M-DNA mass marker. 


\section{References}

1. Whittam, T.S.; Ochman, H.; Selander, R.K. Multilocus genetic structure in natural populations of Escherichia coli. Proc. Natl. Acad. Sci. USA 1983, 80, 1751-1755. [CrossRef] [PubMed]

2. Milkman, R. Electrophoretic variation in Escherichia coli from natural sources. Science 1973, 182, 1024-1026. [CrossRef] [PubMed]

3. Salinas, L.; Cárdenas, P.; Johnson, T.J.; Vasco, K.; Graham, J.; Trueba, G. Diverse Commensal Escherichia coli Clones and Plasmids Disseminate Antimicrobial Resistance Genes in Domestic Animals and Children in a Semirural Community in Ecuador. $m S p h e r e$ 2019, 4, 00316-00319. [CrossRef] [PubMed]

4. Bok, E.; Kożańska, A.; Mazurek-Popczyk, J.; Wojciech, M.; Baldy-Chudzik, K. Extended Phylogeny and Extraintestinal Virulence Potential of Commensal Escherichia coli from Piglets and Sows. Int. J. Environ. Res. Public Health 2020, 17, 366. [CrossRef] [PubMed]

5. Blyton, M.D.; Pi, H.; Vangchhia, B.; Abraham, S.; Trott, D.J.; Johnson, J.R.; Gordon, D.M. Genetic Structure and Antimicrobial Resistance of Escherichia coli and Cryptic Clades in Birds with Diverse Human Associations. Appl. Environ. Microbiol. 2015, 81, 5123-5133. [CrossRef]

6. Nakamura, K.; Murase, K.; Sato, M.P.; Toyoda, A.; Itoh, T.; Mainil, J.G.; Piérard, D.; Yoshino, S.; Kimata, K.; Isobe, J.; et al. Differential dynamics and impacts of prophages and plasmids on the pangenome and virulence factor repertoires of Shiga toxin-producing Escherichia coli O145:H28. Microb Genom. 2020, 6, e000323. [CrossRef]

7. Forde, B.M.; Roberts, L.W.; Phan, M.; Peters, K.M.; Fleming, B.A.; Russell, C.W.; Lenherr, S.M.; Myers, J.B.; Barker, A.P.; Fisher, M.A.; et al. Population dynamics of an Escherichia coli ST131 lineage during recurrent urinary tract infection. Nat. Commun. 2019, 10, 1-10. [CrossRef]

8. Petty, N.K.; Zakour, N.L.B.; Stanton-Cook, M.; Skippington, E.; Totsika, M.; Forde, B.M.; Phan, M.D.; Moriel, D.G.; Peters, K.M.; Davies, M.; et al. Global dissemination of E. coli ST131. Proc. Natl. Acad. Sci. USA 2014, 111, 5694-5699. [CrossRef]

9. Baldy-Chudzik, K.; Bok, E.; Mazurek, J. Well-known and new variants of pathogenic Escherichia coli as a consequence of the plastic genome. Postep. Hig. Med. Dosw. 2015, 17, 345-361. [CrossRef]

10. Donnenberg, M.S.; Whittam, T.S. Pathogenesis and evolution of virulence in enteropathogenic and enterohemorrhagic Escherichia coli. J. Clin. Invest. 2001, 107, 539-548. [CrossRef]

11. Johnson, J.R.; Owens, K.L.; Clabots, C.R.; Weissman, S.J.; Cannon, S.B. Phylogenetic relationships among clonal groups of extraintestinal pathogenic Escherichia coli as assessed by multi-locus sequence analysis. Microbes Infect. 2006, 8, 1702-1713. [CrossRef] [PubMed]

12. Wirth, T.; Falush, D.; Lan, R.; Colles, F.; Mensa, P.; Wieler, L.H.; Karch, H.; Reeves, P.R.; Maiden, M.C.J.; Ochman, H.; et al. Sex and virulence in Escherichia coli: An evolutionary perspective. Mol. Microbiol. 2006, 60, 1136-1151. [CrossRef] [PubMed]

13. Beghain, J.; Bridier-Nahmias, A.; Le Nagard, H.; Denamur, E.; Clermont, O. ClermonTyping: An easy-to-use and accurate in silico method for Escherichia genus strain phylotyping. Microb. Genom. 2018, 4, e000192. [CrossRef] [PubMed]

14. Stoppe, N.C.; Silva, J.S.; Carlos, C.; Sato, M.I.Z.; Saraiva, A.M.; Ottoboni, L.M.M.; Torres, T.T. Worldwide Phylogenetic Group Patterns of Escherichia coli from Commensal Human and Wastewater Treatment Plant Isolates. Front. Microbiol. 2017, 8, 2512. [CrossRef]

15. Clermont, O.; Christenson, J.K.; Denamur, E.; Gordon, D.M. The Clermont Escherichia coli phylo-typing method revisited: Improvement of specificity and detection of new phylo-groups. Environ. Microbiol. Rep. 2013, 5, 58-65. [CrossRef] [PubMed]

16. Clermont, O.; Olier, M.; Hoede, C.; Diancourt, L.; Brisse, S.; Keroudean, M.; Glodt, J.; Picard, B.; Oswald, E.; Denamur, E. Animal and human pathogenic Escherichia coli strains share common genetic backgrounds. Infect. Genet. Evol. 2011, 11, 654-662. [CrossRef]

17. Walk, S.T. Cryptic lineages of the genus Escherichia. Appl. Environ. Microbiol. 2009, 75, 6534-6544. [CrossRef]

18. Clermont, O.; Dixit, O.V.A.; Vangchhia, B.; Condamine, B.; Dion, S.; Bridier-Nahmias, A.; Denamur, E.; Gordon, D. Characterization and rapid identification of phylogroup $\mathrm{G}$ in Escherichia coli, a lineage with high virulence and antibiotic resistance potential. Environ. Microbiol. 2019, 21, 3107-3117. [CrossRef]

19. Rodriguez-Siek, K.E.; Giddings, C.W.; Doetkott, C.; Johnson, T.J.; Fakhr, M.K.; Nolan, L.K. Comparison of Escherichia coli isolates implicated in human urinary tract infection and avian colibacillosis. Microbiology 2005, 151, 2097-2110. [CrossRef]

20. Johnson, T.J.; Kariyawasam, S.; Wannemuehler, Y.; Mangiamele, P.; Johnson, S.J.; Doetkott, C.; Skyberg, J.A.; Lynne, A.M.; Johnson, J.R.; Nolan, L.K. The genome sequence of avian pathogenic Escherichia coli strain O1:K1:H7 shares strong similarities with human extraintestinal pathogenic E. coli genomes. J. Bacteriol. 2007, 189, 3228-3236. [CrossRef]

21. Brzuszkiewicz, E.; Gottschalk, G.; Ron, E.; Hacker, J.; Dobrindt, U. Adaptation of Pathogenic E. coli to Various Niches: Genome Flexibility is the Key. Genome Dyn. 2009, 6, 110-125. [PubMed]

22. Coombes, B.K.; Gilmour, M.W.; Goodman, C.D. The evolution of virulence in non-o157 shiga toxin-producing Escherichia coli. Front. Microbiol. 2011, 2, 90. [CrossRef]

23. Russo, T.A.; Johnson, J.R. Medical and economic impact of extraintestinal infections due to Escherichia coli: Focus on an increasingly important endemic problem. Microbes Infect. 2003, 5, 449-456. [CrossRef]

24. Lutful Kabir, S.M. Avian Colibacillosis and Salmonellosis: A Closer Look at Epidemiology, Pathogenesis, Diagnosis, Control and Public Health Concerns. Int. J. Environ. Res. Public Health 2010, 7, 89-114. [CrossRef] [PubMed]

25. Martínez, R.; Sánchez, S.; Alonso, J.M.; Herrera-León, S.; Rey, J.; Echeita, M.A.; Morán, J.M.; García-Sánchez, A. Salmonella spp . and Shiga toxin-producing Escherichia coli prevalence in an ocellated lizard (Timon lepidus) research center in Spain. Foodborne Pathog. Dis. 2011, 8, 1309-1311. [CrossRef] 
26. Gopee, N.V.; Adesiyun, A.A.; Caesar, K. A longitudinal study of Escherichia coli strains isolated from captive mammals, birds, and reptiles in Trinidad. J. Zoo Wildl. Med. Off. Publ. Am. Assoc. Zoo Vet. 2000, 31, 353-360.

27. Russo, T.A.; Johnson, J.R. Proposal for a new inclusive designation for extraintestinal pathogenic isolates of Escherichia coli: ExPEC. J. Infect. Dis. 2000, 181, 1753-1754. [CrossRef]

28. Bélanger, L.; Garenaux, A.; Harel, J.; Boulianne, M.; Nadeau, E.; Dozois, C.M. Escherichia coli from animal reservoirs as a potential source of human extraintestinal pathogenic E. coli. FEMS Immunol. Med. Microbiol. 2011, 62, 1-10. [CrossRef]

29. Enterobase, enterobase-web, wiki, ecoli MLST Legacy Info RST-Bitbucket. Available online: http:/ / enterobase.warwick.ac.uk/ species/ecoli/allele_st_search (accessed on 22 August 2020).

30. Roer, L.; Overballe-Petersen, S.; Hansen, F. Escherichia coli Sequence Type 410 Is Causing New International High-Risk Clones. mSphere 2018, 3, 1-14. [CrossRef]

31. Riley, L.W. Pandemic lineages of extraintestinal pathogenic Escherichia coli. Clin. Microbiol. Infect. 2014, 20, 380-390. [CrossRef]

32. Day, M.J.; Rodríguez, I.; van Essen-Zandbergen, A. Diversity of STs, plasmids and ESBL genes among Escherichia coli from humans, animals and food in Germany, the Netherlands and the UK. J Antimicrob. Chemother. 2016, 71, 1178-1182. [CrossRef] [PubMed]

33. Ha Lau, S.; Reddy, S.; Cheesbrough, J.; Bolton, F.J.; Willshaw, G.; Cheasty, T.; Fox, A.J.; Upton, M. Major Uropathogenic Escherichia coli Strain Isolated in the Northwest of England Identified by Multilocus Sequence Typing. J. Clin. Microbiol. 2008, 46, 1076-1080. [CrossRef] [PubMed]

34. Alghoribi, M.F.; Doumith, M.; Upton, M. Complete Genome Sequence of a Colistin-Resistant Uropathogenic Escherichia coli Sequence Type 131 fimH22 Strain Harboring mcr-1 on an IncHI2 Plasmid, Isolated in Riyadh, Saudi Arabia. Microbiol. Resour. Announc. 2019, 8, e00104-e00119. [CrossRef] [PubMed]

35. Kim, S.W.; Karns, J.S.; Van Kessel, J.A.S.; Haley, B.J. Genome Sequences of Five Multidrug-Resistant Escherichia coli Sequence Type 117 Isolates Recovered from Dairy Calves. Genome Announc. 2017, 5, e00732-17. [CrossRef]

36. Long, H.; Feng, Y.; Ma, K.; Liu, L.; McNally, A.; Zong, Z. The co-transfer of plasmid-borne colistin-resistant genes mcr-1 and mcr-3.5, the carbapenemase gene blaNDM-5 and the $16 \mathrm{~S}$ methylase gene rmtB from Escherichia coli. Sci. Rep. 2019, 9, 1-6. [CrossRef]

37. Bonnedahl, J.; Drobni, M.; Gauthier-Clerc, M.; Hernandez, J.; Granholm, S. Dissemination of Escherichia coli with CTX-M Type ESBL between Humans and Yellow-Legged Gulls in the South of France. PLoS ONE 2009, 4, e5958. [CrossRef]

38. Kaper, J.B.; Nataro, J.P.; Mobley, H.L. Pathogenic Escherichia coli. Nat. Rev. Microbiol. 2004, 2, 123-140. [CrossRef]

39. Johnson, J.R.; Russo, T.A. Extraintestinal pathogenic Escherichia coli: 'the other bad E coli'. J. Lab. Clin. Med. 2002, 139, 155-162. [CrossRef]

40. Croxen, M.A.; Finlay, B.B. Molecular mechanisms of Escherichia coli pathogenicity. Nat. Rev. Microbiol. 2010, 8, 26-38. [CrossRef]

41. Pawlak, A. Reptile-associated salmonellosis as an important epidemiological problem. Postępy Hig. Med. Dośw. 2014, 17, 1335-1342. [CrossRef]

42. Schmidt, V.; Mock, R.; Burgkhardt, E.; Junghanns, A.; Ortlieb, F.; Szabo, I. Cloacal aerobic bacterial flora and absence of viruses in free-living slow worms (Anguis fragilis), grass snakes (Natrix natrix) and European Adders (Vipera berus) from Germany. EcoHealth 2014, 11, 571-580. [CrossRef] [PubMed]

43. Unger, F.; Eisenberg, T.; Prenger-Berninghoff, E.; Leidner, U.; Ludwig, M.L.; Rothe, M. Imported reptiles as a risk factor for the global distribution of Escherichia coli harbouring the colistin resistance gene mcr-1. Int. J. Antimicrob. Agents 2017, 49, 122-123. [CrossRef] [PubMed]

44. de Carvalho, A.M.; Júnior, A.K.P.; Andrade, M.A.; de Jayme, V.S. Prevalence of Enterobacteriaceae in Tupinambis merianae (Squamata: Teiidae) from a captive facility in Central Brazil, with a profile of antimicrobial drug resistance in Salmonella enterica. Phyllomedusa J. Herpetol. 2013, 12, 57-67. [CrossRef]

45. Gordon, D.M.; Cowling, A. The distribution and genetic structure of Escherichia coli in Australian vertebrates: Host and geographic effects. Microbiol Read. Engl. 2003, 149, 3575-3586. [CrossRef] [PubMed]

46. Książczyk, M.; Kuczkowski, M.; Dudek, B.; Korzekwa, K.; Tobiasz, A.; Korzeniowska-Kowal, A.; Paluch, E.; Wieliczko, A.; Bugla-Płoskońska, G. Application of Routine Diagnostic Procedure, VITEK 2 Compact, MALDI-TOF MS, and PCR Assays in Identification Procedure of Bacterial Strain with Ambiguous Phenotype. Curr. Microbiol. 2016, 72, 570-582. [CrossRef]

47. Vizcarra, I.A.; Hosseini, V.; Kollmannsberger, P.; Meier, S.; Weber, S.S.; Arnoldini, M. How type 1 fimbriae help Escherichia coli to evade extracellular antibiotics. Sci. Rep. 2016, 6, 1-13. [CrossRef]

48. Anderson, G.G.; Palermo, J.J.; Schilling, J.D.; Roth, R.; Heuser, J.; Hultgren, S.J. Intracellular bacterial biofilm-like pods in urinary tract infections. Science 2003, 301, 105-107. [CrossRef]

49. Brooks, D.E.; Cavanagh, J.; Jayroe, D.; Janzen, J.; Snoek, R.; Trust, T.J. Involvement of the MN blood group antigen in shearenhanced hemagglutination induced by the Escherichia coli F41 adhesin. Infect. Immun. 1989, 57, 377-383. [CrossRef]

50. Hultgren, S.J.; Porter, T.N.; Schaeffer, A.J.; Duncan, J.L. Role of type 1 pili and effects of phase variation on lower urinary tract infections produced by Escherichia coli. Infect. Immun. 1985, 50, 370-377. [CrossRef]

51. Baorto, D.M.; Gao, Z.; Malaviya, R.; Dustin, M.L.; van der Merwe, A.; Lublin, D.M. Survival of FimH-expressing enterobacteria in macrophages relies on glycolipid traffic. Nature 1997, 389, 636-639. [CrossRef]

52. Croxen, M.A.; Law, R.J.; Scholz, R.; Keeney, K.M.; Wlodarska, M.; Finlay, B.B. Recent advances in understanding enteric pathogenic Escherichia coli. Clin. Microbiol. Rev. 2013, 26, 822-880. [CrossRef] [PubMed] 
53. Schneider, G.; Dobrindt, U.; Brüggemann, H.; Nagy, G.; Janke, B.; Blum-Oehler, G.; Buchrieser, C.; Gottschalk, G.; Emödy, L.; Hacker, J. The Pathogenicity Island-Associated K15 Capsule Determinant Exhibits a Novel Genetic Structure and Correlates with Virulence in Uropathogenic Escherichia coli Strain 536. Infect. Immun. 2004, 72, 5993-6001. [CrossRef] [PubMed]

54. Köhler, C.D.; Dobrindt, U. What defines extraintestinal pathogenic Escherichia coli? Int. J. Med. Microbiol. 2011, 301, $642-647$.

55. Castellanos, L.R.; Donado-Godoy, P.; León, M. High Heterogeneity of Escherichia coli Sequence Types Harbouring ESBL/ AmpC Genes on IncI1 Plasmids in the Colombian Poultry Chain. PLoS ONE 2017, 12, e0170777. [CrossRef] [PubMed]

56. Maluta, R.P.; Logue, C.M.; Casas, M.R.T.; Meng, T.; Guastalli, E.A.L.; Rojas, T.C.G. Overlapped sequence types (STs) and serogroups of avian pathogenic (APEC) and human extra-intestinal pathogenic (ExPEC) Escherichia coli isolated in Brazil. PLoS ONE 2014, 9, e105016. [CrossRef] [PubMed]

57. Manges, A.R.; Harel, J.; Masson, L.; Edens, T.J.; Portt, A.; Reid-Smith, R.J. Multilocus sequence typing and virulence gene profiles associated with Escherichia coli from human and animal sources. Foodborne Pathog. Dis. 2015, 12, 302-310. [CrossRef]

58. Collins, C.H.; Lyne, P.M. Microbiological Methods, 5th ed.; Butterworths: London, UK, 1985.

59. Miller, J.M. Quality Control in Microbiology; Centers for Disease Control and Prevention: Atlanta, GA, USA, 1987.

60. August, M.J. Quality Control and Quality Assurance Practices in Clinical Microbiology. Am. Soc. for Microbiol. 1990, 3A, 1-14.

61. Basics of Quality Assurance for Intermediate and Peripheral Laboratories, 2nd ed.; WHO Regional Office for the Eastern Mediterranean: Alexandria, Egypt, 2000.

62. Koppes, L.H.; Woldringh, C.L.; Nanninga, N. Size variations and correlation of different cell cycle events in slow-growing Escherichia coli. J. Bacteriol. 1978, 134, 423-433. [CrossRef]

63. Stenutz, R.; Weintraub, A.; Widmalm, G. The structures of Escherichia coli O-polysaccharide antigens. FEMS Microbiol. Rev. 2006, 30, 382-403. [CrossRef]

64. Pulsed-field Gel Electrophoresis (PFGE). PulseNet Methods, PulseNet, CDC. 2017. Available online: https:/ /www.cdc.gov / pulsenet/pathogens/pfge.html (accessed on 22 August 2020). 